Nat. Hazards Earth Syst. Sci., 18, 1427-1450, 2018

https://doi.org/10.5194/nhess-18-1427-2018

(C) Author(s) 2018. This work is distributed under

the Creative Commons Attribution 4.0 License.

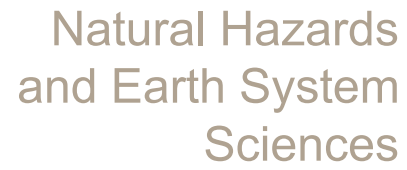

E⿺辶

\title{
The Norwegian forecasting and warning service for rainfall- and snowmelt-induced landslides
}

\author{
Ingeborg K. Krøgli ${ }^{1}$, Graziella Devoli ${ }^{1,2}$, Hervé Colleuille ${ }^{1}$, Søren Boje ${ }^{1}$, Monica Sund ${ }^{1}$, and Inger Karin Engen ${ }^{1}$ \\ ${ }^{1}$ Department of Hydrology, Norwegian Water Resources and Energy Directorate (NVE), Oslo, 0368, Norway \\ ${ }^{2}$ Department of Geosciences, University of Oslo, Oslo, 0316, Norway
}

Correspondence: Ingeborg K. Krøgli (ikl@nve.no)

Received: 30 November 2017 - Discussion started: 19 December 2017

Revised: 20 April 2018 - Accepted: 24 April 2018 - Published: 25 May 2018

\begin{abstract}
The Norwegian Water Resources and Energy Directorate (NVE) have run a national flood forecasting and warning service since 1989. In 2009, the directorate was given the responsibility of also initiating a national forecasting service for rainfall-induced landslides. Both services are part of a political effort to improve flood and landslide risk prevention. The Landslide Forecasting and Warning Service was officially launched in 2013 and is developed as a joint initiative across public agencies between NVE, the Norwegian Meteorological Institute (MET), the Norwegian Public Road Administration (NPRA) and the Norwegian Rail Administration (Bane NOR). The main goal of the service is to reduce economic and human losses caused by landslides. The service performs daily a national landslide hazard assessment describing the expected awareness level at a regional level (i.e. for a county and/or group of municipalities). The service is operative 7 days a week throughout the year. Assessments and updates are published at the warning portal http://www.varsom.no/ at least twice a day, for the three coming days. The service delivers continuous updates on the current situation and future development to national and regional stakeholders and to the general public. The service is run in close cooperation with the flood forecasting service. Both services are based on the five pillars: automatic hydrological and meteorological stations, landslide and flood historical database, hydro-meteorological forecasting models, thresholds or return periods, and a trained group of forecasters. The main components of the service are herein described. A recent evaluation, conducted on the 4 years of operation, shows a rate of over $95 \%$ correct daily assessments. In addition positive feedbacks have been received from users through a questionnaire. The capability of the service to fore-
\end{abstract}

cast landslides by following the hydro-meteorological conditions is illustrated by an example from autumn 2017. The case shows how the landslide service has developed into a well-functioning system providing useful information, effectively and on time.

\section{Introduction}

Early warning systems (EWSs) have been defined by UN/ISDR (2009) as "a set of capacities needed to generate and disseminate timely and meaningful warning information to enable individuals, communities and organization, threatened by a hazard to prepare and to act appropriately and in sufficient time to reduce losses". They must comprise four elements: risk knowledge, monitoring and warning services, dissemination and communication, and response capability (UN/ISDR, 2006). A worldwide overview of existing EWSs for rapid mass movements and for weather-induced landslides is available in Stähli et al. (2015) and Calvello (2017). Based on the size of the area covered by the system, landslide EWSs can be separated into (a) local, focusing on a single landslide at slope scale, and (b) territorial, focusing on multiple landslides at regional scale, over a basin, municipality, region or nation (Bazin, 2012; Calvello, 2017). Stähli et al. (2015) recognized three main categories of EWSs for rapid mass movements: alarm, warning, and forecasting systems (Table 1).

The number of existing territorial and landslide forecasting systems seems to have increased in recent years ( $\mathrm{Pi}$ ciullo et al., 2018). Calvello (2017) suggests that this can be due to better cost effectiveness, compared to the real- 
Table 1. Type of EWS for rapid mass movements and weather-induced landslides, combined from Stähli et al. (2015) and Calvello (2017). Quotes are from Stähli et al. (2015).

\begin{tabular}{|c|c|c|}
\hline \multicolumn{2}{|c|}{ Type of EWS } & \multirow{2}{*}{$\begin{array}{l}\text { Explanation } \\
\text { "It detects process parameters of ongoing hazard events to initiate an alarm } \\
\text { automatically, e.g., in the form of red flashing lights accompanied by sirens. } \\
\text { The accuracy of the prediction is high, but the lead time is short. The alarm } \\
\text { decision is based on a predefined threshold." }\end{array}$} \\
\hline Local & Alarm & \\
\hline & Warning & $\begin{array}{l}\text { "It aims to detect significant changes in the environment (time-dependent fac- } \\
\text { tors determining susceptibility with respect to mass release), e.g., crack open- } \\
\text { ing, availability of loose debris material and potential triggering events (e.g., } \\
\text { heavy rain), before the release occurs and thus allows specialists to analyse } \\
\text { the situation and implement appropriate intervention measures. The informa- } \\
\text { tion content of the data is often lower in this early stage, but the lead time is } \\
\text { extended. The initial alert is based on predefined thresholds." }\end{array}$ \\
\hline Territorial & Forecasting & $\begin{array}{l}\text { "It predicts the level of danger of a rapid mass movement process, typically at } \\
\text { the regional scale and at regular intervals. In contrast to warning systems, the } \\
\text { data interpretation is not based on a simple threshold but is conducted on a regu- } \\
\text { lar basis, e.g., daily. Experts analyse sensor data and consult models to forecast } \\
\text { the regional danger levels, which are communicated widely in a bulletin." }\end{array}$ \\
\hline
\end{tabular}

ization of structural mitigation measures; easy applicability over large and densely populated areas where the risk to people is widespread; upgraded technologies; and more reliable models in weather forecasts. However, this could also be explained by the fact that several territorial EWSs working operationally have started to become visible in international literature just recently, mainly in the last 5 years, like the EWS from Alerta-Rio, from Brazil (D’Orsi, 2012) operating since 1997. Others are still not well known outside their own region, typically due to a lack of international publication and documentation. This is the case for the Norwegian service, described in this document. It is challenging for territorial and local operational EWSs to reconcile typical operational tasks with research activities and dissemination of experiences to an international audience. Often, especially for territorial services, operational activities and continuous improvement of the service seem to have higher priority than publicizing the latest development internationally. For some services, frequent catastrophic events may also limit the required time and attention to publish articles. Furthermore, documentation is often published in the original language of the service first, sufficient for the direct users, but less accessible to international readers.

The existing operative services around the world focus on prediction, warning and sending alarm to the population about possible occurrence of fast-moving landslides, usually shallow, which are triggered by intense rainfall and/or snowmelt. These landslides fall in the category of flow-type landslides (Hungr et al., 2001) like debris flows, debris flood, debris avalanches, but translational or rotational debris and soil slides can also be observed (Hungr et al., 2014). They occur in steep slopes, usually covered by Quaternary loose deposits (like tills deposits, volcanic sediments, loess, lateritic soils). Because of their long runout and high velocity, they are responsible of large damages and casualties worldwide (Dowling and Santi, 2014). In regions covered by snow, slushflows, another rapid mass movement, may also be triggered during rainfall and snowmelt episodes. Slushflows are movements of water-saturated snow which initiate in gentle slopes and are characterized by long runouts (Washburn and Goldthwait, 1958; Hestnes, 1985). Their high density and velocity have caused dozens of fatalities as well as the destruction of buildings and closure of roads and railways (Hestnes, 1998).

With the general name "rainfall- and snowmelt-induced landslides", used herein, we refer to debris flows, debris flood, debris avalanches, translational or rotational debris and soil slides and slushflows, because they often occur under the same rainfall and/or snowmelt episodes. They regularly occur in clusters, in large number and scattered over a large area, happening frequently together with floods.

These types of landslides cause yearly significant damages in Norway to roads and railways, buildings, and other infrastructure. It is expected that climate changes, with more intense rainfall and increased temperatures, will contribute to an increase in landslide hazard (Gariano and Guzzetti, 2016; Hanssen-Bauer et al., 2017). It is estimated that every year about 200 of these events hit road sectors and about 30 hit railways (Hisdal et al., 2017). Norway has a long tradition of building physical structures (i.e. diversion dikes, tunnels, etc.) to protect road and railway lines in the most critical sites. Protection measures are still useful, but their maintenance is expensive and the building operations are time consuming. The climatic and topographic conditions in Norway 
indicate that it is an impossible task to provide $100 \%$ protection of the national infrastructure. Therefore, forecasting and warning have become a crucial mitigation option to reduce risks.

Here we present the Norwegian Landslide Forecasting and Warning Service (known as "Jordskredvarslingen" in Norwegian). The service, or some of its components, has been partly presented and described in conference proceedings and previous articles (i.e. Devoli et al., 2014; Boje et al., 2014a; Bell et al., 2014; Piciullo et al., 2017). The service, presented herein, can be categorized as a "territorial" EWS following Calvello (2017) and as "forecasting and warning type" based on Stähli et al. (2015). The service is designed to predict the level of danger of rainfall- and snowmeltinduced landslides. The service predicts multiple landslides at national scale, in particular over a region (which is commonly an administrative county or a group of municipalities) on a regular basis (every day). As for the majority of territorial systems described in Calvello (2017) and Piciullo et al. (2018), the Norwegian one, presented herein, is also managed by a governmental institution that uses warning dissemination tools to warn multiple weather-induced hazards, including floods and snow avalanches. The service uses specialists to analyse meteorological and hydrogeological models and forecasts, sensor data, and predefined national and regional thresholds. Finally, the regional danger level is widely communicated through a bulletin.

The Norwegian Water Resources and Energy Directorate (NVE) is a directorate under the Ministry of Petroleum and Energy and is responsible for the administration of Norway's water and energy resources and the coordination of national efforts for landslide and snow avalanche risk prevention. NVE operates three forecasting services (landslide, flood, and snow avalanche) and several local warning systems for large rockslides (Engeset, 2013; Blikra and Kristensen, 2013). NVE has run a national flood forecasting and warning service since 1989. Back in 2009, the directorate was given the responsibility of also initiating a national forecasting service for rainfall-induced landslides (white papers: Meld. St. 22, 2007-2008; Meld. St. 15, 2011-2012). Both services are part of a political effort to improve flood and landslide risk prevention.

The development of EWSs for landslides started in February 2010 based on suggestions in Colleuille and Engen (2009). The landslide forecasting service started an operational test phase in January 2012. This service was officially launched in October 2013 and is run in close cooperation with the National Flood Forecasting and Warning Service. Since then, the service has operated continuously at regional scale for mainland Norway. The service is developed as a joint initiative across public agencies between NVE, the Norwegian Meteorological Institute (MET), the Norwegian Public Road Administration (NPRA) and the Norwegian Rail Administration (Bane NOR).
This work summarized the efforts made in the last 5 years by NVE and collaborators to design, develop, and run a nationwide landslide forecasting and warning service in close synergy with the Norwegian Flood Forecasting and Warning Service. The main purpose of this article is to describe the recent development and main components of the service, also indicating how the service is organized and how daily assessments are performed. We present the evaluation of the accuracy of assessments and use a case study as an example. Finally we present some feedbacks from regional and local emergency authorities on the usefulness of this new service.

\section{Major floods and landslides in Norway}

The mainland of Norway (Scandinavian Peninsula) covers an area of $324000 \mathrm{~km}^{2}$, with more than $490000 \mathrm{~km}$ of rivers and streams and around 250000 lakes. The country has large climatic contrasts, from maritime to continental climate, because of rugged topography that causes large local differences. The average annual precipitation is about $1400 \mathrm{~mm}$, of which about one-third is snow. The precipitation distribution is non-uniform. In Western Norway, annual precipitation may exceed $5000 \mathrm{~mm}$ and daily values of $70 \mathrm{~mm}$ are not uncommon. In the east, some valleys annually receive less than $300 \mathrm{~mm}$. The Fennoscandian Shield constitutes the Precambrian bedrock of Scandinavia. The oldest rocks, dating back 2.5 billion years, can be found in Northern Norway. Above the bedrock lie remnants of the Caledonian mountain range, while the youngest rocks are to be found in the Oslo Rift and provide evidence of volcanic activity 250-300 million years ago (Solli and Nordgulen, 2006). During the Quaternary, ice sheets covered Scandinavia several times. This resulted in poorly weathered but fractured bedrock without primary porosity, and young, sparse and thin sedimentary deposits. The aquifers in Norway mainly consist of (a) small, highly permeable glaciofluvial aquifers along streams and lakes, (b) small precipitation-fed tills in mountainous areas and (c) overlying fractured bedrocks without primary porosity, such as crystalline and metamorphosed hard rocks. The tills have limited storage capacity and groundwater responds fast to water input (rain and snowmelt). There are very few large and slowly responding groundwater reservoirs in Norway. A recharge-discharge mechanism determined by the physiographic and climatic conditions controls the groundwater level (Colleuille et al., 2007). In winter, precipitation falls as snow and the ground may freeze. This leads to a decrease in groundwater levels and increase in soil water storage capacity and contributes to surface runoff in streams and rivers. Following soil thaw and snowmelt in spring, groundwater levels rise rapidly.

Major natural hazards in Norway are extreme weather (wind storm, intense rainfalls), floods and different types of mass movements. Rock fall, rock slides, rock avalanches, mountain deformations (with a tsunamigenic potential), de- 

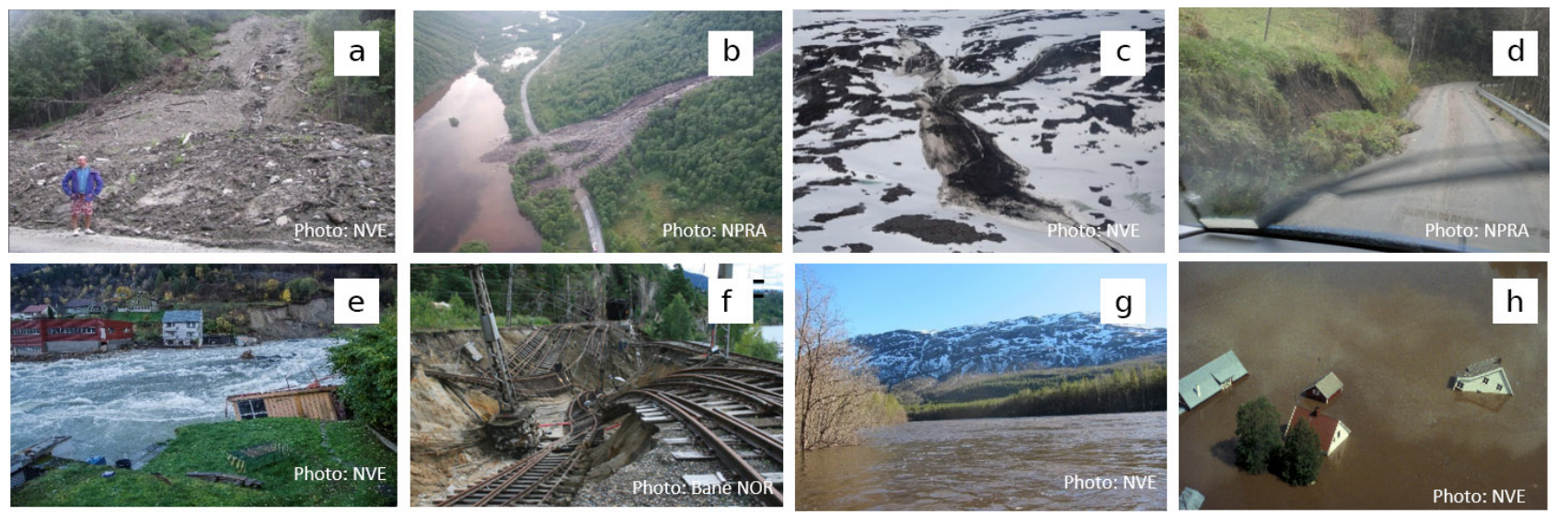

Figure 1. Examples of landslides and flood types in Norway. (a) Debris slide. Veikledalen, Oppland, May 2011. (b) Debris flow. Mjåland, Rogaland, June 2016. (c) Slushflow. Troms, May 2010. (d) Soil slide. Vennesla, Vest-Agder, October 2017. (e) Rain flood. River Opo in Odda, Hordaland, October 2014. (f) Flash flood. Notodden, Telemark, July 2011. (g) Snowmelt-induced flood. The river Reisa, Troms, May 2013. (h) Combined rainfall- and snowmelt-induced flood. River Glomma, Hedmark, June 1995.

bris avalanches, debris flows, debris slides, rotational clay slides, and quick-clay slides are the most frequent landslide types in Norway (NVE, 2011). Different types of snow avalanches can be observed and slushflows are also common rapid mass movements (Fig. 1a-d).

The main flood types in Norway are rain flood, flood due to snowmelt, the combination of rainfall- and snowmeltinduced flood, and flash flood due to intense rainfall, the last of which especially in summer (Fig. 1e-g). It is the combination of rainfall- and snowmelt-induced flood that historically results in the largest floods in Norway, both in return periods and extent (e.g. south-eastern Norway, in 1995 and 2013). In coastal areas rain flood in autumn usually results the largest floods. This especially is the case for Western Norway and Northern Norway. In some glacial valleys, jøkulhlaup (glacier lake outburst flood) is a reoccurring and potentially dangerous event. Flood due to sudden release of water in ice dammed rivers, and flooding of riverbanks due to ice dames, are also a phenomenon well known in Norway, both during mild periods in winter and in springtime (Roald, 2013).

Rainfall- and snowmelt-induced landslides are triggered by water. Intense or long-duration water supply, caused by rain and/or snowmelt, increases the water content in the soil or snow. The cohesiveness of soil or snow particles decreases with higher water content, increasing the risk for mass transportation. Not only steep natural slopes covered by loose Quaternary sediments but also gentle slopes covered by snow as well as modified slopes and filling along roads and railways are especially exposed to these kinds of hazards. Climate scenarios for Norway indicate an increased occurrence of extreme weather, and intense precipitation is also expected to increase especially in the coastal areas of Norway (MET, 2013). Higher temperatures have led to earlier spring floods, and there is a tendency to increased frequency of rain floods.
Future projections show that rain flood magnitude will increase, while snowmelt floods will decrease over time. More frequent and stronger intense rainfall events may in the future create specific challenges in small, steep rivers and in urban areas. Weather conditions are main triggers of certain types of landslides and snow avalanches; therefore changes in climate may affect their future frequency. The risk of slushflows will increase and may occur in areas where they have not occurred previously (Hanssen-Bauer et al., 2017).

The experience acquired from landslide events in Norway since 2011 shows that they can occur all year round. Important and recent landslides events are presented in Table 2.

There are limited comprehensive estimates of human and economic losses associated with natural hazards in Norway (e.g. floods and mass movements). In terms of fatalities, about 2000 persons have lost their lives in the past 150 years because of mass movements. Most of these casualties have been due to snow avalanches (Nadim et al., 2008). For landslides in soil, Aaheim et al. (2010) reported that 100 people have died since 1900 and most of the casualties are related to clay slides and quick-clay slides, often triggered by anthropogenic factors. Few data are available for casualties related to rainfall- and snowmelt-induced landslides. An effort to document fatalities associated with these landslide types was done by NVE in 2016 as part of the work presented in Haque et al. (2017) where landslides fatalities have been presented for the whole o Europe. For Norway the analysis showed that 42 people died in the period 1995-2016 due to 25 landslide events in the category of debris flows, debris avalanches, clay slides, quick-clay slides, rock falls, rock avalanches, and slushflows. The results indicated that 2005 and 2010 were the years with most recorded fatalities (ca. six persons). Most of the fatalities were caused by rock falls and rock avalanches, 7 because of clay-type slides, while 12 people died because of rainfall- and snowmelt-induced land- 
Table 2. A selection of significant landslide events in Norway in the period 2013-2017 listed from north to south. In the list the landslide events that also occurred before 2013 and used for the definition of thresholds are indicated. The general geomorphological and geological conditions are also indicated, as well as the main landslide types in the regions. Asterisks indicate that rainfall were remnants of tropical cyclones.

\begin{tabular}{|c|c|c|c|c|c|c|}
\hline Area & Year & Date & $\begin{array}{l}\text { Name of } \\
\text { extreme } \\
\text { weather }\end{array}$ & Triggering & $\begin{array}{l}\text { Max. } 24 \mathrm{~h} \text { rainfall in- } \\
\text { tensity in the area } \\
\text { (from xgeo.no) }\end{array}$ & $\begin{array}{l}\text { Approx. number of } \\
\text { landslide events }\end{array}$ \\
\hline \multicolumn{7}{|c|}{$\begin{array}{l}\text { Northern Norway: alpine relief or glacial relief, steep slopes }\left(25-45^{\circ} \text { and }>45^{\circ}\right) \text { with glacio-fluvial deposits; colluvial } \\
\text { deposits; mainly debris slides and debris flows }\end{array}$} \\
\hline Nordland & 2013 & $\begin{array}{l}\text { December } \\
(10-12)\end{array}$ & Ivar & Intense rainfall & $\begin{array}{l}80-100 \mathrm{~mm} \\
\text { (locally up to } \\
100-150 \mathrm{~mm} \text { ) }\end{array}$ & $\sim 50-100$ events \\
\hline $\begin{array}{l}\text { Nordland and } \\
\text { Trøndelag }\end{array}$ & 2014 & $\begin{array}{l}\text { December } \\
(30-31)\end{array}$ & Mons & Intense rainfall & $\begin{array}{l}40-60 \mathrm{~mm} \\
\text { (locally up to } \\
60-80 \mathrm{~mm} \text { ) }\end{array}$ & $\begin{array}{l}<50 \text { events; many } \\
\text { slushflows }\end{array}$ \\
\hline
\end{tabular}

Central Norway: hilly terrain dominated by marine clay deposits, locally steep slopes $\left(25-45^{\circ}\right)$; mainly debris and clay slides, some debris flows

\begin{tabular}{lllllll}
\hline $\begin{array}{l}\text { Trøndelag, } \\
\text { Møre og Roms- } \\
\text { dal, Sogn } \\
\text { og Fjordane, }\end{array}$ & 2013 & $\begin{array}{l}\text { November } \\
(15-16)\end{array}$ & Hilde & Intense rainfall & $80-100 \mathrm{~mm}$ & $>100$ events \\
Hordaland & & & & & & \\
\hline Trøndelag & 2015 & October (1-2) & Roar & Intense rainfall & $\begin{array}{l}60-80 \mathrm{~mm} \\
\text { (locally up to } \\
100-150 \mathrm{~mm})\end{array}$ & $<50$ events \\
\end{tabular}

Western Norway: alpine relief or glacial relief, steep slopes $\left(25-45^{\circ}\right.$ and $\left.>45^{\circ}\right)$ with glacio-fluvial deposits; colluvial deposits; mainly debris flows and debris avalanches

\begin{tabular}{|c|c|c|c|c|c|c|}
\hline $\begin{array}{l}\text { Sogn og } \\
\text { Fjordane, } \\
\text { Hordaland, } \\
\text { Rogaland }\end{array}$ & 2005 & September (14) & Kristin $(*)$ & Intense rainfall & $100-150 \mathrm{~mm}$ & $50-100$ events \\
\hline $\begin{array}{l}\text { Møre og Roms- } \\
\text { dal, Sogn } \\
\text { og Fjordane, } \\
\text { Hordaland, Ro- } \\
\text { galand }\end{array}$ & 2005 & $\begin{array}{l}\text { November } \\
(14-15)\end{array}$ & Loke $(*)$ & Intense rainfall & $100-150 \mathrm{~mm}$ & $>100$ events \\
\hline $\begin{array}{l}\text { Sogn og Fjor- } \\
\text { dane, Horda- } \\
\text { land, Rogaland, } \\
\text { Agder }\end{array}$ & 2015 & $\begin{array}{l}\text { December } \\
(4-6)\end{array}$ & Synne & Intense rainfall & $\begin{array}{l}60-80 \mathrm{~mm} \\
\text { (locally up to } \\
80-100 \mathrm{~mm} \text { ) }\end{array}$ & $\begin{array}{l}\sim 50-100 \text { events; some } \\
\text { slushflows }\end{array}$ \\
\hline $\begin{array}{l}\text { Sogn og } \\
\text { Fjordane, } \\
\text { Hordaland, } \\
\text { Rogaland }\end{array}$ & 2016 & $\begin{array}{l}\text { January } \\
(29-30)\end{array}$ & Tor & Intense rainfall & $40-60 \mathrm{~mm}$ & $<50$ events \\
\hline $\begin{array}{l}\text { Sogn og } \\
\text { Fjordane, } \\
\text { Hordaland, } \\
\text { Rogaland }\end{array}$ & 2017 & $\begin{array}{l}\text { December } \\
(7-8)\end{array}$ & Aina & Intense rainfall & $\begin{array}{l}60-80 \mathrm{~mm} \\
\text { (locally up to } \\
80-100 \mathrm{~mm} \text { ) }\end{array}$ & $<50$ events \\
\hline $\begin{array}{l}\text { Møre og Roms- } \\
\text { dal, Sogn } \\
\text { og Fjordane, } \\
\text { Hordaland, } \\
\text { Rogaland }\end{array}$ & 2017 & $\begin{array}{l}\text { December } \\
(22-23)\end{array}$ & Birk & Intense rainfall & $\begin{array}{l}60-80 \mathrm{~mm} \\
\text { (locally up to } \\
80-100 \mathrm{~mm} \text { ) }\end{array}$ & $\sim 50-100$ events \\
\hline
\end{tabular}


Table 2. Continued.

\begin{tabular}{|c|c|c|c|c|c|c|}
\hline Area & Year & Date & $\begin{array}{l}\text { Name of } \\
\text { extreme } \\
\text { weather }\end{array}$ & Triggering & $\begin{array}{l}\text { Max. } 24 \mathrm{~h} \text { rainfall in- } \\
\text { tensity in the area } \\
\text { (from xgeo.no) }\end{array}$ & $\begin{array}{l}\text { Approx. mumber of } \\
\text { landslide events }\end{array}$ \\
\hline \multicolumn{7}{|c|}{$\begin{array}{l}\text { Southern and Eastern Norway: hilly terrain dominated by marine clay deposits, gentle slopes }\left(<25^{\circ} \text { locally up to } 45^{\circ}\right) \text {; } \\
\text { mainly clay and debris slides }\end{array}$} \\
\hline $\begin{array}{l}\text { Oslo, Akers- } \\
\text { hus, Buskerud, } \\
\text { Telemark }\end{array}$ & 2000 & $\begin{array}{l}\text { October- } \\
\text { December }\end{array}$ & - & $\begin{array}{l}\text { Prolonged rain- } \\
\text { fall and high } \\
\text { ground water } \\
\text { level }\end{array}$ & $\begin{array}{l}40-60 \mathrm{~mm} \text { (many rain- } \\
\text { fall episodes during } \\
3 \text { months) }\end{array}$ & $\sim 50-100$ events \\
\hline $\begin{array}{l}\text { Agder, Tele- } \\
\text { mark, Buskerud }\end{array}$ & 2015 & $\begin{array}{l}\text { September } \\
(14-17)\end{array}$ & Petra & $\begin{array}{l}\text { Prolonged rain- } \\
\text { fall and high } \\
\text { ground water } \\
\text { level }\end{array}$ & $40-60 \mathrm{~mm}$ & $\begin{array}{l}<50 \text { events; some } \\
\text { debris flows }\end{array}$ \\
\hline $\begin{array}{l}\text { Rogaland, } \\
\text { Agder, Tele- } \\
\text { mark }\end{array}$ & 2017 & $\begin{array}{l}\text { September- } \\
\text { October } \\
(30-2)\end{array}$ & $(*)$ & Intense rainfall & $\begin{array}{l}100-150 \mathrm{~mm} \\
(\text { locally }>150 \mathrm{~mm})\end{array}$ & $\begin{array}{l}\sim 50-100 \text { events; some } \\
\text { debris flows }\end{array}$ \\
\hline $\begin{array}{l}\text { Agder, Tele- } \\
\text { mark }\end{array}$ & 2017 & $\begin{array}{l}\text { September- } \\
\text { October } \\
(21-22)\end{array}$ & Ylva & Intense rainfall & $80-100 \mathrm{~mm}$ & $<50$ events \\
\hline \multicolumn{7}{|c|}{$\begin{array}{l}\text { Eastern Norway: glacially scoured low mountains and valleys, steep slopes }\left(25-45^{\circ} \text { and }>45^{\circ}\right) \text { with glacio-fluvial } \\
\text { deposits; mainly debris flows and debris slides }\end{array}$} \\
\hline $\begin{array}{l}\text { Oppland, } \\
\text { Hedmark, } \\
\text { Buskerud, } \\
\text { Telemark }\end{array}$ & 2013 & $\begin{array}{l}\text { May } \\
(15-16) \\
(22-23)\end{array}$ & - & $\begin{array}{l}\text { Intense rainfall } \\
\text { and intense } \\
\text { snowmelt }\end{array}$ & $40-60 \mathrm{~mm}$ & $\begin{array}{l}>100 \text { events; some } \\
\text { slushflows }\end{array}$ \\
\hline
\end{tabular}

slides (of these 7 due to slushflows and 5 due to both debris flows and debris avalanches).

In terms of economic losses, there are no reliable estimates of the total cost to society due to natural hazards, although insurance payments can provide an indication of cost trends. Payments made by insurance companies in Norway between 1980 and 2014 show both an increase in numbers of damaging events and increase in number of total claims per year, reaching around NOK 2500 million ( $\sim$ EUR 275 million) in the flood and landslides event of June 2011 in south-eastern Norway. However these numbers are underestimated since they do not include events and costs associated with public infrastructure (NIFS, 2016).

\section{The Norwegian landslide forecasting and warning service}

\subsection{Components}

A sustainable EWS for rainfall-induced landslides requires not only strong and reliable meteorological, hydrological, hydrogeological, or geotechnical models as pointed out by Baum and Godt (2010) but also meteorological, hydrological, hydrogeological, and geotechnical networks; a national landslide database to support threshold development, probability analysis, and verification; geographically specific warning thresholds; a uniform, national-scale shallow susceptibility map or hazard map; computer and communications networks to support the operation; and an operational infrastructure and dedicated professional staff. Political commitments and dedicated investments are also crucial. The service needs to be integrated as part of national and local disaster risk management plans and budgets, and enforceable legislation must define roles and responsibilities of local to national authorities and agencies involved. Because of the multidisciplinary characteristic of these types of landslides, the cooperation among agencies should be effective. Finally, the service requires systematic feedback and evaluation at all levels to ensure improvement, implementation/commitment over time and systematic field verifications (UN/ISDR, 2006). The main components of the Norwegian landslide forecasting and warning service are described in the following sections.

\subsubsection{Meteorological forecasts and hydrological models}

The service uses daily meteorological quantitative gridded forecasts of precipitation and temperature, obtained from the Norwegian Meteorological Institute (MET). The forecasts are obtained from different weather models: AROMEMetCoOp (short-term forecasts use in the Scandinavian re- 
gions in cooperation MET Norway with Swedish Meteorological and Hydrological Institute and Finnish Meteorological Institute; Müller et al., 2017) and EC, which is a global long-term model from the European Center for Medium-Range Weather Forecasts (https://www.ecmwf. int/). The short-term model's resolution is $2.5 \mathrm{~km}$ and is used for the $+66 \mathrm{~h}$ forecast and updated four times a day. The long-term model's resolution is $9 \mathrm{~km}$, forecasts for nine days ahead and is updated twice a day.

Due to the relatively sparse station network and relative short measurements periods, hydrological models are a prerequisite to describe the water and energy balances on a national scale. The service uses forecasted hydrometeorological variables obtained by a distributed version of the hydrological HBV model (Beldring et al., 2003). The model divides Norway into $1 \mathrm{~km}^{2}$ grid cells (total over 385000 cells), where each cell is treated as a separate basin with a corresponding simulation of the water balance. The model simulates, for example, runoff, snowmelt, groundwater, soil saturation and soil frost, based on two types of input data: temperature and precipitation. Forecasted values are obtained from downscaling of the AROME and EC weather prediction models, while observed values are based on interpolated values from MET's nationwide network. The model is automatically running four times per day. Several of the models simulated variables can be found at http://www.xgeo. no as maps (see Sect. 3.1.6).

We use, in addition to the distributed HBV model, a onedimensional soil water and heat flow model (S-Flow) developed by NVE. This model simulates water and heat dynamics in a layered soil column covered by vegetation. S-Flow uses equations adapted mostly from the COUP (Jansson and Karlberg, 2014) and SHAW (Flerchinger, 2000) models. The model runs with a daily time step, using precipitation, air temperature, wind speed, relative humidity and sun radiation (or cloud cover) data as input. In addition, plant growth characteristics and soil characteristics are necessary inputs to the model. Simulations with S-Flow are performed only in areas where groundwater stations are located (about 45 points), where observations are used for the parameterization of the model. The model runs daily and the results, such as water supply (snowmelt and rain), soil water deficit, groundwater level, and soil frost, are available at http://www.xgeo.no (see Sect. 3.1.6). The S-Flow model has a better physical description than the HBV model of the snowmelt and evaporation process as it uses a physically based approach and all available meteorological information. In addition to the estimation of soil-water deficit, S-Flow includes soil-water depletion following the fall in groundwater levels in winter caused by lack of recharge and groundwater discharge into streams and lakes (Colleuille et al., 2007).

\subsubsection{Meteorological and hydrological network}

The service uses several networks. We access data from meteorological stations, equipped with rain gauge (hourly and daily data), temperature sensors and snow and wind sensors, and operated mostly by MET but also by NPRA and Bane NOR. Hydrological stations are used to measure discharge in rivers, snow depth, and coverage (over 400 stations) and hydrogeological stations to measure groundwater level (70 stations) and are operated by NVE.

Real-time observations of rainfall, air temperature, water discharge, and ground water level are used in the daily landslide hazard assessment to check the performance of the hydro-meteorological conditions obtained from the hydrological models. This is particularly important when the models overestimate or underestimate certain parameters values (i.e., the soil water saturation or the snowmelt) in certain regions or in certain seasons. Real-time discharge data are used to automatically assimilate and correct the modelled discharge in watercourses and are most used for flood forecasting, but they can also give valuable information about the debris flow hazards. Historical data on soil moisture, soil frost, and groundwater have been mainly used to test and calibrate the physically based S-Flow model.

\subsubsection{Landslide database}

Landslide records are essential for different types of analyses, e.g. threshold establishment, calibration of models in warning systems and evaluation of warning performance. Landslide data can be collected using two interfaces: http://www.regobs.no/ (see Sect. 3.1.9) and https:// www.skredregistrering.no/. This last one is the web portal for the national mass movement database, containing landslide and snow avalanche events and was established in 2001. The database has registrations from historical times, but $70 \%$ of the registrations are recorded after 2000 . The database contains around 65000 events in the categories of rock fall, rock avalanche (of different sizes), debris flow, debris slide/debris avalanches and shallow soil slide in artificial slopes, snow avalanche, icefall, and landslide in clay (quick-clay slides and rotational clay slides). In addition some events can be recorded as unspecified when the subtype is unknown. The database is maintained by NVE, but several institutions have registered data, among them the NPRA, the Geological Survey of Norway (NGU), the Norwegian Geotechnical Institute (NGI) and Bane NOR. The data are accessible through NVE Atlas (https://atlas.nve.no) and http: //www.xgeo.no (see Sect. 3.1.6). The landslides are represented by points positioned where the event caused losses of life, damages or traffic interruptions. The database contains valuable information for thresholds analyses. However, because of the many limitations, a quality control is always performed before any type of analysis. 
Thresholds for landslide hazard

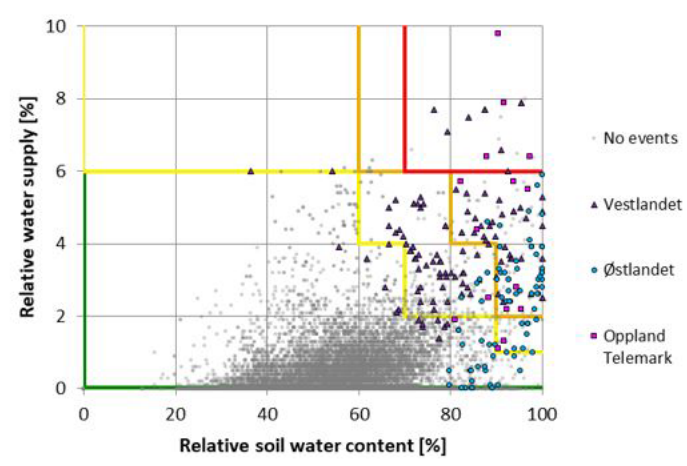

(a)

\section{(b) Thresholds for landslide hazard (c) for Eastern Norway}
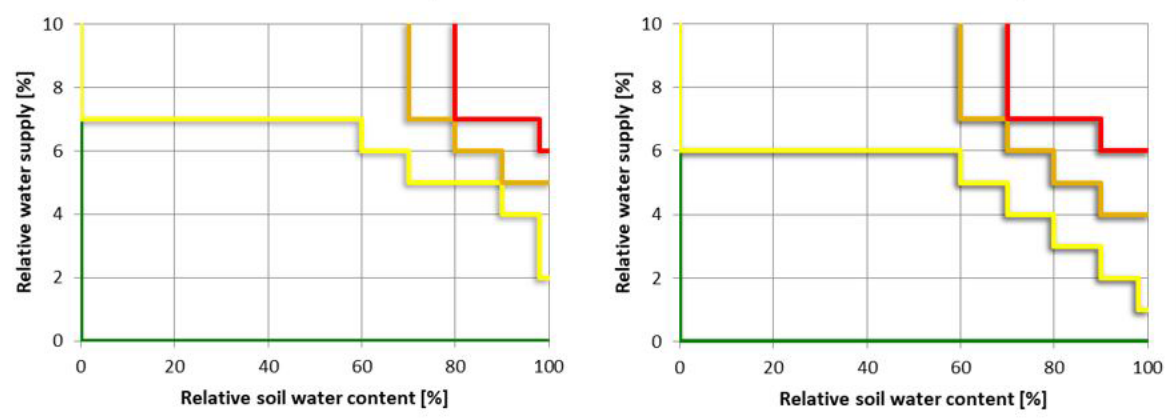

Figure 2. The landslide hazard thresholds used by the Norwegian landslide early warning and forecasting service. (a) National thresholds, (b) regional threshold for Southern Norway and (c) regional threshold for Eastern Norway.

\subsubsection{Thresholds}

Most landslide EWSs use intensity-duration curves for rainfall as thresholds (Guzzetti et al., 2008; Piciullo et al., 2018; Segoni et al., 2018a; Bogaard and Greco, 2018). Based on the threshold classification proposed by Guzzetti et al. (2008), we can affirm that the Norwegian system uses "other thresholds". The development of the Norwegian forecasting system is based on the principle that since hydro-meteorological parameters can be predicted, forecasting of landslide hazard is possible. The knowledge of these relationships is used to develop threshold values by investigating the time of past landslide events and meteorological and hydrological variables. Modelled hydro-meteorological variables obtained from a distributed $1 \mathrm{~km}^{2}$ grid version of the conceptual HBV model (Beldring et al., 2003) and cross-checked with the time of previous landslides were used to statistically derive thresholds (Colleuille et al., 2010; Cepeda et al., 2012; Cepeda, 2013a, b; Boje et al., 2014b). A regression analysis was performed, that used a decision tree classification technique similar to Kirschbaum et al. (2015).

The best performance was obtained when the relative water supply and the soil water saturation degree were combined. This result is not unexpected and is in line with the findings of some recent works on landslide rainfall thresholds (Capra et al., 2018; Segoni et al., 2018b). The relative water supply is derived from simulated rain or snowmelt from the snowpack (in which rain may percolate), as a percentage of an annual average value for a 30 -year period. The degree of soil water saturation (\%) describes the relationship between simulated total water content in the soil (groundwater and soil water) normalized by the maximum soil water content simulated for a 30-year period, which is assumed equal to a fully saturated soil. The 30 -year reference period for both variables is 1981-2010. The HBV uses only precipitation and air temperature in order to discriminate precipitation into rain or snow and to simulate snow pack accumulation and snowmelt. The model uses a one-dimensional soil bucket approach, accounting for the storage of water in the soil (Bergstrøm, 1995; Beldring et al., 2003).

The thresholds are visualized in Fig. 2a-c. All thresholds are also visualized in the form of raster data (with $1 \mathrm{~km} \times 1 \mathrm{~km}$ resolution) and available at http://www.xgeo. no. Figure $2 \mathrm{a}$ shows the national thresholds, while Fig. $2 \mathrm{~b}$ and $\mathrm{c}$ show regional thresholds. The development of the national thresholds was done using relatively few weather events in the south of Norway, but each with many landslides in the categories of rapid shallow slides, debris avalanches 
and debris flows. These weather events occurred in Southern and Eastern Norway (2000), Western Norway (2005), and Eastern Norway (2008). The first one could be categorized as a low-intensity but prolonged rainfall event over several months, responsible of the full saturation of the soil, the second was a typical intense rainfall event that was the remnants of tropical cyclones reaching Norway and the third one was a typical snowmelt episode due to very high temperatures.

The grey points are days without landslide events, while coloured triangles and circles show days with landslide occurrence. The figure shows three lines (yellow, orange, and red) that correspond to the minimum, medium, and maximum threshold respectively. As pointed out by Aleotti (2004), for practical, and hence operational, purposes, the minimum threshold is of special interest, since above this threshold, landslides are expected to occur. The medium and maximum thresholds were decided manually by evaluating the spatial distribution of the threshold map and its impact colours (green, yellow, orange, red) with regard to the abundance of expected landslides at a regional scale (Cannon and Ellen, 1985). Below the yellow threshold, landslides are not expected, while over the red line, many landslides are expected to occur. A closer view of the figure shows that under the yellow thresholds some landslides can be also observed. A recent quality control of these data revealed their poor quality (i.e. uncertain date of occurrence; many in modified slopes and not only rainfall-induced), suggesting that these events should have been excluded from the dataset.

To these lines we assigned colours similar to our warning levels to indicate that the hazard is high over the red line, while below the yellow line the hazard is low. Looking at the plot of the landslide events it is clear that there are regional differences because of the different geomorphological and geological conditions, as well as for the hydrometeorological triggering conditions. The plotted landslides from Western Norway are displayed almost separately from landslides from Eastern Norway, and with Telemark and Oppland events somewhat in between. In Table 2, the differences between these regions are also illustrated.

Most recently, the thresholds are being adapted to take into account these regional physiographic and climatic differences (Boje et al., 2017). New thresholds have been defined for two regions: Southern Norway and Eastern Norway (Fig. 2b-c), both where many false alarms were sent in recent years based on the national thresholds. It has been used improved and high-quality landslide records obtained since 2013, as well as assessed days without landslides. A challenge for these two regions was too few recorded landslides in order to carry out a statistically viable regression analysis. The approach has been to manually adjust the original minimum yellow threshold upwards. Based on the recent cases with false alarms, the thresholds were simply increased until no impact was shown in the threshold map. In this approach, the quality assessment of the days with no landslides was crucial and based on the daily monitoring of landslide events performed by the operational EWS.

The described procedure for the definition of the thresholds lacks in objectivity and is not easily reproducible, like for many other published empirical rainfall thresholds (Guzzetti et al., 2008; Segoni et al., 2018a). However, we are working on a way to better describe and specify the mathematical and statistical criteria used in the thresholds definition, as well as to improve the quality of the landslide datasets to be used in the analysis. Although a study of thresholds for different landslide types has not been conducted yet, we consider that this could be of interest to test in the future.

\subsubsection{Susceptibility maps}

A susceptibility map shows the spatial probability of landslides, e.g. the probability that a region will be affected by landslides given a set of terrain conditions. Two maps (Fig. 3) that can be used to predict the spatial occurrence of rainfalland snowmelt-induced landslides in Norway have been prepared, both of them covering the entire country. The first map shows which first-order catchments are more susceptible to landslide in soil (e.g. debris avalanches, debris flows, shallow soil slides, clay slides and quick-clay slides) (Bell et al., 2014). The map was prepared combining different variables, like Quaternary cover map, land cover, average yearly rainfall, various water runoff variables, and various derivatives from the $15 \mathrm{~m} \times 15 \mathrm{~m}$ digital elevation model (DEM), i.e. slope and aspect. It was done using the Generalized Additive Models (GAM) (Fig. 3a). This map has been used to improve the original threshold map (see Sect. 3.1.4) by including information on landslide-prone areas and the result of this combination was a new threshold map. This is used by the forecasters in the initial phase to perform a more accurate assessment.

The second susceptibility map shows specifically where debris avalanches and small debris flows may occur at 1 : 50000 scale (Fischer et al., 2012, 2014). The map displays the modelled potential source areas, tracks, and runout areas. The source areas were discriminated based on an index approach, which includes topographic parameters, obtained from a $10 \mathrm{~m}$ digital terrain model (i.e. slope angle, planar curvature) and hydrological settings (i.e. drainage area). For the runout modelling, the Flow-R model was used, which is based on combined probabilistic and energetic algorithms for the assessment of the spreading of the flow and maximum runout distances. This map is used in the communication phase of the warning, since it can be viewed at http://www.varsom.no/ (see Sect. 3.1.8) together with the warning zone and warning level. The user can zoom in on the map of the warning zone and see where landslides could occur (Fig. 3b). 

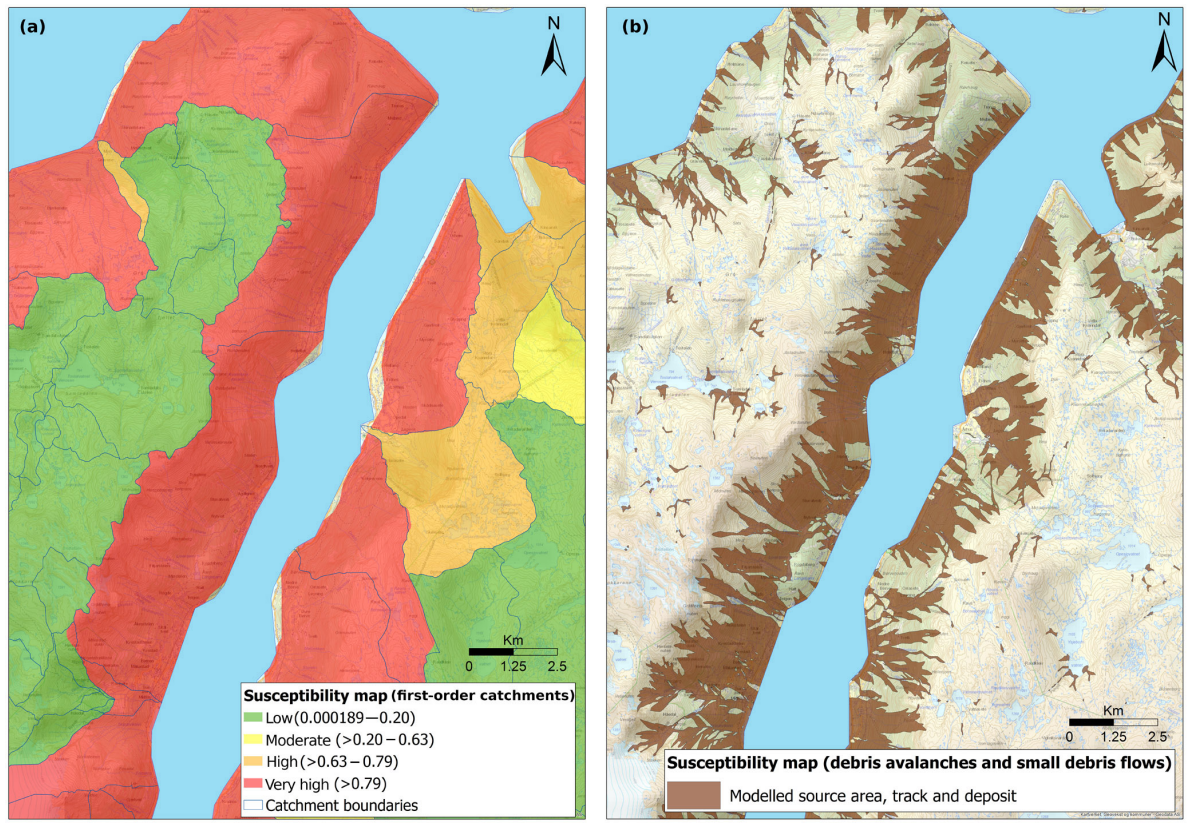

Figure 3. Susceptibility map for landslides in soil at Sørfjorden, Western Norway: (a) at first-order catchments from Bell et al. (2014); (b) at $1: 50000$ scale, from Fischer et al. (2014).

\subsubsection{Web tools: xgeo - an analysis and decision making tool}

Xgeo.no is a decision-making tool used by forecasters for snow avalanches, landslides, and floods. Even though its use is aimed at specialists, data are made available to the public thanks to an open data policy through http://www.senorge.no (Engeset et al., 2004). The web portal, developed and maintained since 2008 is a map-centric tool for visualization of temporal and spatial data (Barfod et al., 2013). The portal shows daily observations and forecasts for meteorological and hydrological conditions as thematic maps and timeseries data. The maps, updated four times a day, show the conditions for each day, and for 9 days ahead and reach back to 1957. Landslide specialists use this tool during the daily evaluation to visualize, for example, real-time measurements, weather forecast, threshold values predictions, water supply and groundwater simulations, data from the real-time database regObs (see Sect. 3.1.9), landslide events from the national mass movement database (see Sect. 3.1.3), roads closed because of landslides, and other administrative data, such as existing infrastructure (Devoli et al., 2014).

The hydro-informatics team at NVE has developed http: //www.xgeo.no/, in cooperation with the MET, NPRA, Bane NOR, and the Norwegian Mapping Authority (Kartverket). The tool http://www.xgeo.no/ is systematically updated.

\subsubsection{Operational infrastructure and staff}

The organization of the landslide forecast service rests heavily on the organization of the flood forecast service. It was important to maintain and not disorganize the wellfunctioning flood forecast service during the development of the landslide service. This was ensured by establishing a parallel group of landslide forecasters. The landslide forecasting team consists of people with different backgrounds, such as hydrologists, geologists, geophysicists, hydrogeologists and physical geographers. The team consists, in 2017, of $12 \mathrm{em}-$ ployees from NVE and 2 from NPRA. Five of the landslide forecasters work also as flood forecasters and two of them as snow avalanche forecasters. Landslide and flood forecasters closely discuss the daily landslide and flood assessments. This synergy effect leads to improvements and strengthening for both services. The assessment of slushflows is done in collaboration with the snow avalanche forecasting service, which provides additional information on snow structure and snow condition. There is still an ongoing effort to synchronize the three services groups where possible, and ideas and information are exchanged.

The service is operative 7 days a week, throughout the year, with a rotating scheme with one forecaster on duty. Outside of working hours, forecasters can be reached by mobile phone (08:00-21:00). Forecasters may have to be available $24 / 7$ when there is a severe situation. Courses and training workshops are organized yearly to educate landslide forecasters, discuss new tools and exchange ideas. Many of these courses and workshops are organized together with flood forecasters as well.

Besides available and dedicated personnel as forecasters, the service benefits from skilled IT personnel who also have a strong dedication. The real-time network and forecasting 


\section{Flood and landslide forecast}

$\underline{E}$ > Flood and landside forecast

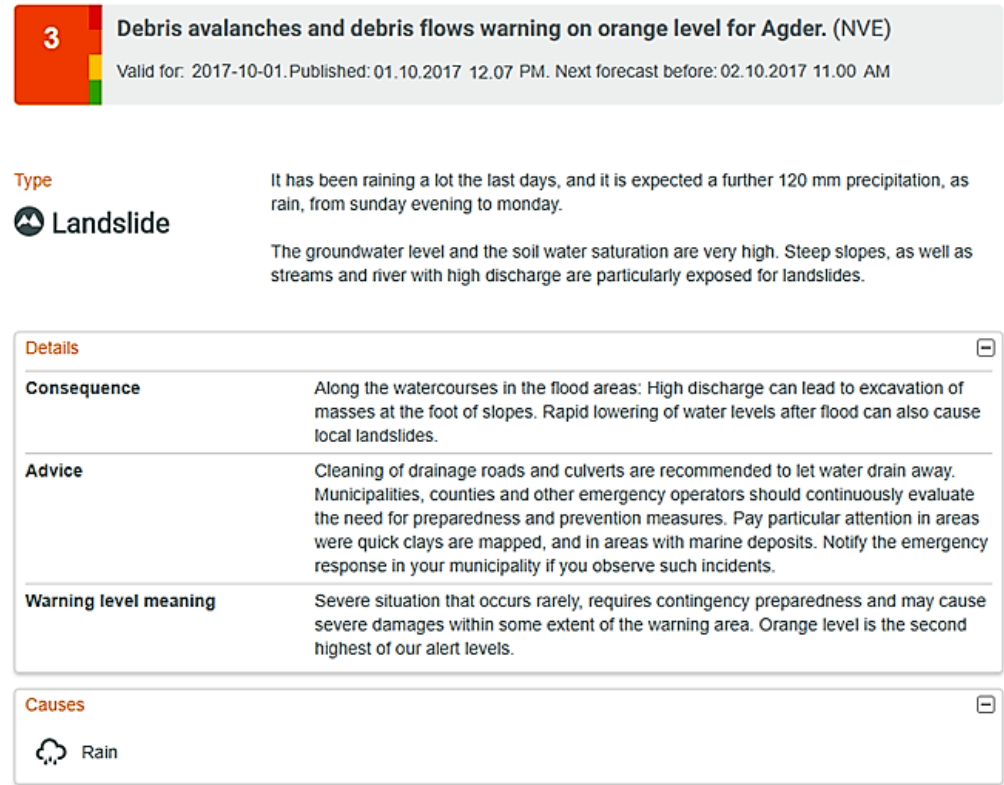

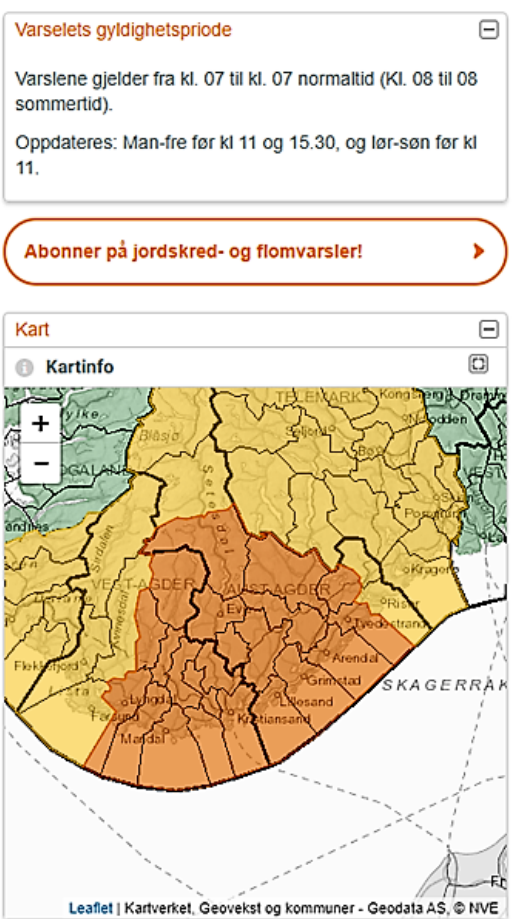

Figure 4. Example of landslide warning bulletin, as viewed on http://www.varsom.no/. The example presented is for the bulletin issued on 1 October 2017, the same case study as in Sect. 6.

tools are set up with redundant systems. In the case of internet failure, routines have been developed to secure minimum communication both to ensure meteorological data and to convey the resulting possible heightened warning level and situation report to the public.

\subsubsection{Communication network: varsom.no, SMS, and CAP}

The national web portal for flood, landslides, snow avalanches warning and ice conditions on regional scale is http://www.varsom.no/. The web was chosen as the main channel for communicating bulletins and warning levels to end-users according to the decision on open access. During development, high priority was given to accessibility on mobile screens, according to the need for making bulletins available to the users "on site" and because of the rapidly increasing numbers of smartphone users (Johnsen, 2013). The web portal displays both bulletins and related maps for the natural hazards covered by the NVE's forecasting and warning services, but it also provides additional information on precautions, educational literature, and videos and relevant reports. Through http://www.varsom.no/ the landslide service delivers continuous updates on the current situation and development to national and regional stakeholders and the public. Assessments are published at least twice a day and contain the forecast for today, tomorrow, and the day after tomorrow.
The landslide forecast is valid from 07:00 the day of publication to 07:00 the following day (08:00 to 08:00 for daylight saving time).

The bulletin is provided in one version only, covering both the need of the general public and the contingency personnel. Due to the regional aspect of the EWS, the technical information provided is limited. The public and the emergency authorities are recommended to make local assessments and decide on the most appropriate measures. The forecaster on duty is available for consulting by phone or e-mail. The bulletins are in Norwegian, but an English version was launched in January 2018. An example of a landslide warning bulletin is presented in Fig. 4.

The software regVars has been developed to enable the publication of flood and landslide bulletins in http://www. varsom.no/. It provides possibilities for drafting bulletins before they are published, enabling ample time for preparation and quality assurance. The bulletins for all three forecasting services are available at http://api.nve.no/ free of charge. Since early 2017 , it has been possible to subscribe to warning messages published at http://www.varsom.no/. The subscription available at https://abonner.varsom.no is easily managed and free of charge. Users choose which natural hazards they want to be notified about (e.g. flood, snow avalanche or landslides) and on what warning levels. They can also choose if they want to receive the notification as an SMS or e-mail or both. In any case, they receive an URL 


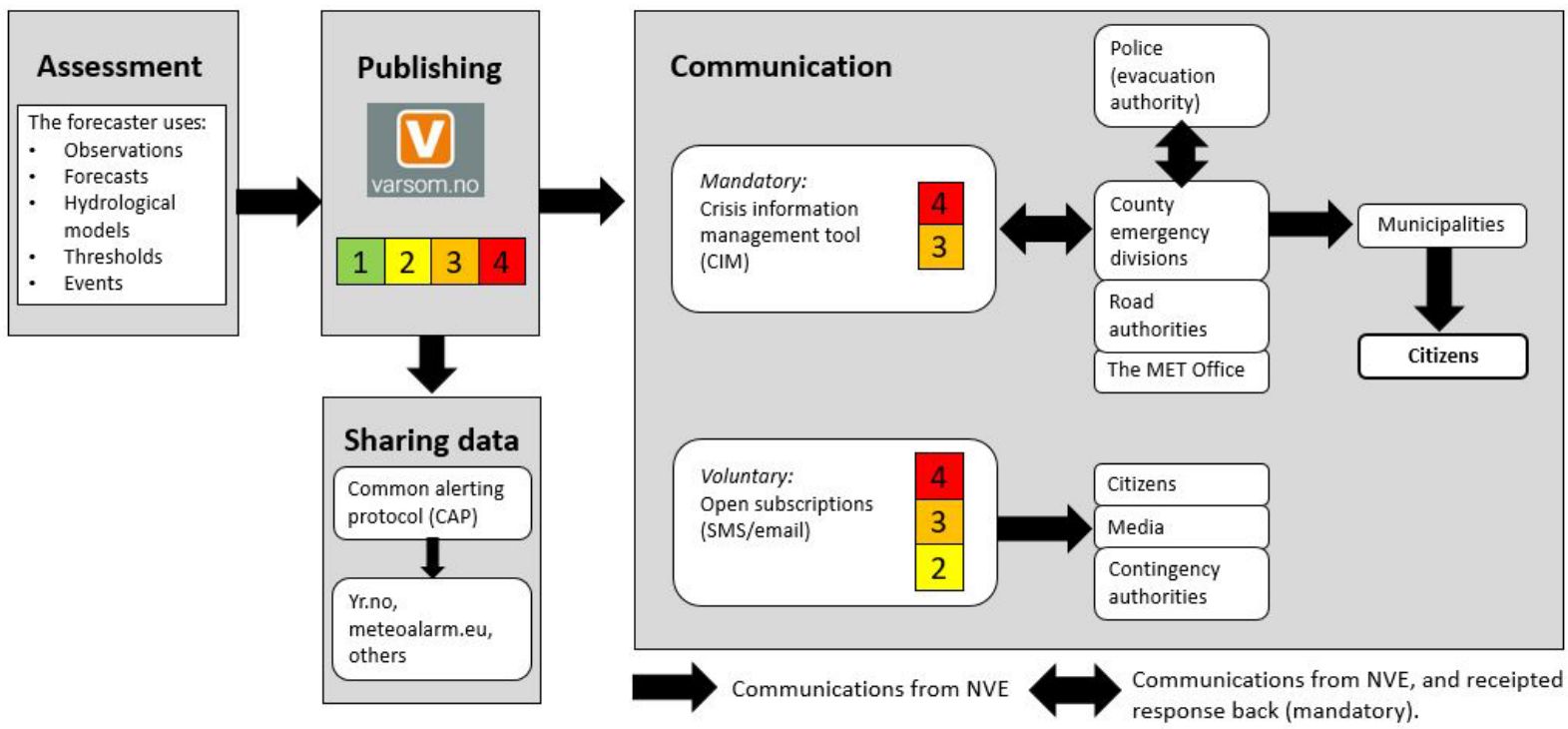

Figure 5. The communication chain of the landslide hazard warnings.

that leads them directly to the relevant warning bulletin at http://www.varsom.no/. It is possible to subscribe for all of Norway, for landslide, flood and snow avalanche, for all warning levels, or just for one municipality and one hazard. All local and regional emergency authorities are encouraged to subscribe. In the case of the two highest warning levels, NVE in addition uses a crisis information management tool (CIM) to notify the relevant county's emergency division by e-mail that warnings have been sent. The county has the responsibility to forward the message to the respective municipalities. MET, NPRA's traffic service, and NVE's regional offices are also contacted via CIM. In these cases, the recipients must reply to NVE that the warning message is received, read, and understood. Figure 5 describes the communication chain, from the assessment done by the forecaster on duty to the publishing on web to the dissemination to the citizens, via the regional and local administrations.

In 2017 NVE and MET started a project in order to use the Common Alerting Protocol (CAP), which is an international data format for emergency alerting and public warning, for distributing warning notifications on severe/extreme weather, floods, landslides, and snow avalanches and to try to harmonize warning procedures and products. The use of CAP is the first of its kind in Norway and serves as the start of a Norwegian standard (CAP-NO) which may be used for other types of alerts. The goal of this project is to improve communication and effectiveness of the warning services. NVEs CAP fees are available at https://cap.nve.no.

\subsubsection{Verification of landslide occurrence: regObs (a crowdsourcing tool) and media monitoring}

The landslide forecasting depends on the registration of landslide events. Landslide events are used for both the develop- ment of thresholds and the evaluation of a sent warning to confirm if the warning was correct or not. Therefore it is important to confirm that a landslide event has occurred after a specific triggering rainfall event (Devoli et al., 2017). We use different sources to verify the occurrence of landslides. The website http://www.regobs.no/ (the abbreviation "regObs" standing for "register observations") is a real-time registration tool for observations, danger signs and events to be used by forecasters and emergency personnel (Ekker et al., 2013). When regObs began in 2010, it was a tool for submitting and sharing of snow avalanche observations. Later, this realtime database was extended to register observations related to other natural hazards like landslides, floods, and ice conditions. It was designed as a public tool supporting crowdsourcing, which means that everyone may contribute observations and all data are immediately available to the public on the regObs website and in the app (http://www.regobs.no/). Both NVE and NPRA stand behind the development of regObs. The data are treated as initial information and are subsequently quality-assured before they are stored in the national mass movement database (see Sect. 3.1.3) and flood database.

Information from local or national newspapers provides one of the fastest sources for obtaining data on landslides affecting infrastructure. Therefore, tools for media monitoring of events are also used as a part of the daily routine to evaluate the issued warning levels. Nevertheless, the accuracy of the reported event may be poor; therefore, a detailed aftermath examination of the facts is essential. Proximity to important infrastructure influences the media coverage rather than the severity of the landslide. Events in more sparsely populated areas may not be covered by this information source. Besides media, we can collect landslide informa- 


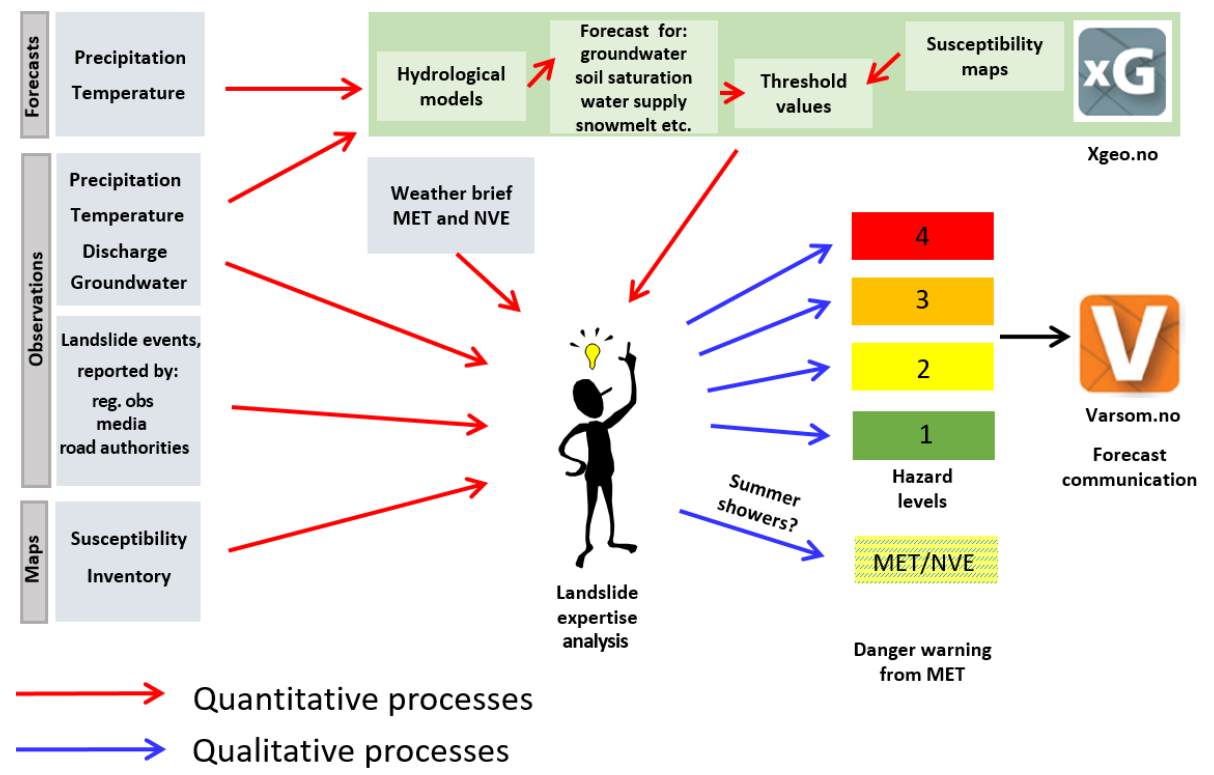

Figure 6. Synthesis of how the daily landslide hazard assessment is performed.

tion through landslide specialists working at NVE's regional offices and landslide specialists from NPRA and Bane NOR that monitor and report landslide events, after field surveys.

\section{Daily assessment and warning levels}

The daily landslide hazard assessment is performed by a forecaster who uses forecasted thresholds, forecasted hydrometeorological parameters, information from real-time observations, knowledge on historical events and regional susceptibility, and personal experience. The daily landslide assessment routine is summarized in Fig. 6 and includes the following phases:

- weather forecast, also as input for the hydrological model;

- model run, forecasted hydro-meteorological parameters, forecasted threshold;

- collection of real-time data;

- interpretation of model results and use of additional information from simulated hydro-meteorological parameters, i.e. snow and groundwater conditions;

- analysis of forecasted thresholds also corrected with susceptibility information;

- preparation of forecast information and warning messages with description of possible events and expected impact;

- communication and dissemination of messages to warn the public and local authorities;

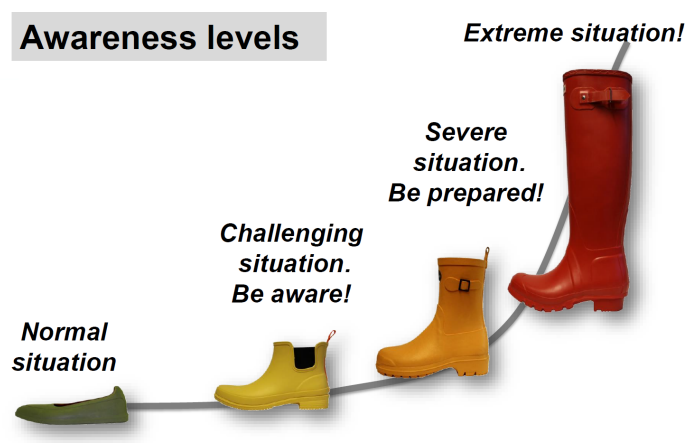

Figure 7. Popular representation of the awareness levels, symbolized by rubber boots.

- provision of hydrological situation updates and answers to questions from media or another recipients.

The warning scale is applicable for both flood and landslide hazards and consists of four levels using the same concept as meteoalarm (http://www.meteoalarm.eu/). The different levels show the landslide hazard and the recommended awareness (Table 3), providing information on what is expected to occur, the severity (qualitative estimation of numbers and dimensions of landslides) and recommended actions that the users should undertake or which measures should be initiated in order to reduce potential damages (Fig. 7).

The principle behind the awareness levels is that the highest level (red) occurs very rarely, while the second lowest level (yellow) occurs more often. Just for comparison, the red level corresponds to a flood with a return period of more than 50 years, while the yellow level corresponds to a flood with a return period of $2-5$ years. 
Table 3. Awareness levels used in the Norwegian landslide forecast and warning service.

\begin{tabular}{ll}
\hline Significance of the awareness levels \\
\hline Red awareness level & $\begin{array}{l}\text { Very high landslide hazard. Many landslides and several large ones may occur; their long runout } \\
\text { and extent may result in damage to settlements and infrastructures. Red awareness level is an } \\
\text { extreme situation that occurs very rarely. Safety measures such as closed roads and evacuations } \\
\text { can occur on short notice. Emergency response authorities should have implemented emergency } \\
\text { plans and mitigation measures for carrying out evacuations and other contingency responses. } \\
\text { Pay attention to the media and follow recommendations from the authorities. }\end{array}$ \\
\hline Orange awareness level & $\begin{array}{l}\text { High landslide hazard. Many landslides and some large ones that can damage infrastructure } \\
\text { and roads may occur. Exposed roads may be closed off. Emergency response authorities should } \\
\text { be prepared to implement emergency plans and mitigation measures and evaluate the need for } \\
\text { evacuations and other contingency responses. Mitigation measures such as clearing water chan- } \\
\text { nels should be carried out. Pay attention to the media and follow recommendations from the } \\
\text { authorities. }\end{array}$ \\
\hline $\begin{array}{l}\text { Moderate landslide hazard, primarily shallow slides on artificial slopes that may affect roads, } \\
\text { railways or river embankments. Isolated debris avalanches or debris flows can occur and could } \\
\text { cause damages to infrastructure and people. At this level emergency authorities should increase } \\
\text { vigilance related to landslides and pay attention to weather forecasts and landslide forecasts and } \\
\text { information at http://www.varsom.no/. Preventive measures are recommended, such as clearing } \\
\text { water channels in exposed areas. }\end{array}$ \\
$\begin{array}{l}\text { Generally safe conditions. Debris avalanches, debris flows, shallow slides, and slushflows are } \\
\text { not expected at this level; however other landslide types (like rock falls, clay slides, and quick- } \\
\text { clay slides) may occur, caused by slow response processes, such as erosion, freeze-thaw weath- } \\
\text { ering or human activity, such as deposition, digging or blasting. These incidents may occur at } \\
\text { all awareness levels. }\end{array}$ \\
\hline Green awareness level
\end{tabular}

Emergency response authorities should be prepared to implement emergency plans, considering available resources, implementing preventive measures, safeguarding exposed assets, and carrying out evacuations and other contingency responses. One of the mitigation measures recommended is to ensure unhindered water channels, e.g. that culverts are not obstructed by ice, snow, sediments or other matter.

\section{Validation of the forecasting service}

Golnaraghi (2005) and UN/ISDR (2006) expressed that "one of the most effective measures for disaster preparedness is a well-functioning early warning system that delivers accurate information dependably and on-time". Therefore a useful EWS is the one capable of issuing correct warning messages which are easily understood and provided early enough to lead municipalities and contingency planners, emergency authorities to action in order to avoid or reduce damages due to landslides. This implies that a successful service requires periodically assessments of the technical performance and user perception (Devoli et al., 2017). In our service, we evaluate the so-called technical performance and the user perception.

\subsection{Technical performance}

The technical performance is evaluated by measuring the accuracy of the service, i.e. quantifying how well the landslide warning performs (correct alarms, false alarms, missed events, wrong levels). It is assumed that a service that delivers warnings at a good time in advance will be perceived as credible and will trigger action by users. Bad hits, with many false alarms and/or more unannounced events, will have the opposite effect.

The evaluation of the performance is based on the fact that the landslide warning is a regional service that warns of landslides over a large area. The daily assessment is considered as correct when the situation meets the description of the awareness level presented in Table 3. This means, for example, that if an orange warning has been issued for a particular region, it is expected in this region that many landslides, some possibly large, have occurred, and that many roads have been closed. In short, this means that it was useful for municipalities and transport authorities to have been prepared and to have implemented some mitigation measures. If the situation was not so severe (no or few events or troubles), the warning may be considered as a wrong level or as a false alarm. In the same way, a day with "green awareness level" with several events may in a region be considered as a "missed event". 
Table 4. Percent of days with awareness level green, yellow, orange and red.

\begin{tabular}{lrrrrrr}
\hline & 2013 & 2014 & 2015 & 2016 & 2017 & $2013-2017$ \\
\hline Green & 81.7 & 83.0 & 90.4 & 93.0 & 89.8 & 87.6 \\
Yellow & 16.0 & 15.0 & 8.5 & 7.0 & 8.0 & 10.9 \\
Orange & 2.0 & 2.0 & 1.1 & 0.0 & 2.2 & 1.4 \\
Red & 0.3 & 0.0 & 0.0 & 0.0 & 0.0 & 0.1 \\
\hline
\end{tabular}

Each week, evaluation of the daily hazard assessment is carried out based on a comparison of warning levels issued and the number of events and hazard signs reported by the media or recorded by the road and railway authorities and municipalities (see Sect. 3.1.9). Updated and new information about landslide events may be available several weeks after the event, and therefore the performance evaluation will undergo another quality assurance after the first evaluation.

Table 4 shows the percent of days when green, yellow, orange, and red awareness levels have been issued in Norway, in the period 2013-2017. The yellow, orange, and red levels are issued for a specific warning zone. The green awareness is given for all of Norway when there is no landslide hazard present. When a yellow, orange, and/or red warning is issued for a specific warning area, the green awareness is given for the remaining of Norway. The table shows that most of the time we give a green level for a high percentage of days (87.6\% in the period 2013-2017), while the yellow level has been issued for $10.9 \%$ of the days in the same period and orange for $1.4 \%$ of the days. The table shows that a red level was seldom issued, and only in 2013.

Table 5 shows two ways to estimate the technical performance: by using all days or only "challenging days". We define "challenging days" as days with demanding assessment, i.e. days where, in addition to reliable hydrological forecast, the expertise and experience of the forecaster on duty is crucial. A demanding assessment may conclude in a green awareness level, as well as yellow, orange or red. About 25-30\% of the days per year are considered as "challenging". This is often in periods with large amounts of rain or high snowmelt, or both.

This statistical analysis shows a performance, at national scale, of about $96 \%$ correct assessment using all days, and about $88 \%$ considering only "challenging days", in the period 2013-2017. The performance evaluation described here reflects four factors. How good are the threshold values? How good are the hydrological simulations? How good are the weather forecasts? How well did the forecaster on duty assess the situation? The performance is of the same magnitude as for the flood forecasting service. False alarms and unexpected events are in most cases due to changes in weather forecasts. Some false alarms and unexpected events are also due to errors in the hydrological models or incorrect interpretation of the model results.
The performance evaluation described above is challenging because it is based on subjective qualitative assessments. Therefore semi-quantitative classification criteria have been suggested to help the daily performance evaluation. The performance of the landslide service was also tested with the EduMaP (Event, Duration Matrix, Performance) method proposed by Calvello and Piciullo (2016). It has been adapted to the Norwegian landslide forecasting and warning service (taking into account the variable warning areas) and tested for Western Norway for the years 2013-2014, and the results are presented in Piciullo et al. (2017). Based on the results from both methods we have started to work on the regional improvement of a landslide threshold, as has been done for Southern and Eastern Norway, contributing in the reduction of false alarms in these regions (Boje, 2017).

\subsection{User perception}

A warning, if correctly received and understood, should contribute to a better preparedness and generate a series of actions. User surveys will provide the basis for an assessment of the value of the service. How do we best use the forecasts, and other products, prepared by the service? How do we communicate the risk?

We have performed two evaluations among users. The first survey was conducted among emergency response officers in the municipalities, county deputy chiefs and infrastructure owners, such as the NPRA and Bane NOR, for a sample of 588 people (Epinion AS, 2017). We asked, among other questions, "How important for the user is the NVE landslide forecasting?" and "How much does the user trust the NVE landslide forecasting?". Results show that a large majority of users consider the landslide forecasting service useful or very useful and they have quite or very much confidence with the warning notifications published at http://www.varsom.no/.

The second evaluation was conducted among a working group, with personnel from NVE, MET, NPRA, Bane NOR, and a county emergency office, that was assigned to carry out an evaluation of the snow avalanche and landslide forecasting service (Hisdal et al., 2017). The group made the evaluation based on the following criteria: development of the services, how the services work today, costs, benefits for the users, measures to improve the benefits, analysis of the number of snow avalanches, and the synergy between flood and landslide services. The working group concluded that the landslide service contributes to a more secure society. To improve the accuracy of the notifications and utility of the service, four priority areas are recommended: increased communication and building of capacity among users, improvement of hazard assessment, improvement of models and tools, and better landslide occurrence verification. 
Table 5. Performance estimation (in \%) for all days, and for days with challenging assessment only.

\begin{tabular}{lrrrrr|rrrrr}
\hline & \multicolumn{5}{c}{ For all days } & \multicolumn{4}{c}{ Only for "challenging days" } \\
\cline { 2 - 10 } & 2013 & 2014 & 2015 & 2016 & 2017 & 2013 & 2014 & 2015 & 2016 & 2017 \\
\hline Correct & 94.2 & 92.9 & 97.9 & 98.0 & 96.6 & 85.0 & 80.0 & 93.4 & 91.8 & 87.5 \\
False alarm & 3.3 & 5.2 & 1.4 & 0.8 & 1.9 & 8.5 & 14.5 & 4.4 & 3.1 & 7.0 \\
Missed events & 2.2 & 1.2 & 0.3 & 1.0 & 1.1 & 5.8 & 3.5 & 0.9 & 4.1 & 4.0 \\
Wrong level & 0.3 & 0.7 & 0.4 & 0.2 & 0.4 & 0.7 & 2.0 & 1.3 & 1.0 & 1.5 \\
\hline
\end{tabular}

\section{Case study: Southern Norway, autumn 2017}

Southern Norway is the area that includes the counties of Rogaland and Agder (e.g. Vest-Agder and Aust-Agder). As indicated in Devoli and Dahl (2014) and later in Devoli et al. (2017) the region is characterized by predominant hills and low relief with gentle slopes $\left(<25^{\circ}\right.$ locally up to $\left.45^{\circ}\right)$ along the coastlines, as well as moderate slopes to elevated hills $\left(<25^{\circ}\right.$, but locally $\left.25-45^{\circ}\right)$ in the interior. Alpine relief and steep slopes are observed in the valleys oriented in a N-S direction. The area is covered with tills, but along the coast and in the alluvial plains the soil coverage is thicker, with fluvial deposits, used for agriculture. In the eastern parts of Agder, near the coastline, there are also marine deposits.

For landslide forecasters these areas have been challenging since the start of the operations. The region is known to be an area with few landslide records, even though the area may receive large amounts of rain in autumn and sometimes in summer and winter. Along the coastline a few debris slides and some soil slides in artificial slopes have been registered in the database (https://www.skredregistrering.no). Many of these records had few details (i.e. unknown landslide type, day of occurrence, etc.), and many slides were not triggered by natural causes (i.e. rainfall/snowmelt) and occurred in days without rainfall, possibly triggered by anthropogenic factors. In the interior of the region, records of debris flows and debris slides are almost absent, and the few ones present have poor quality and are very uncertain. The lack of landslide records is also due to the low population density and transportation lines. From the experience acquired in the last 5 years and evidenced by the warning performance evaluations realized so far (see Sect. 5) it was clear that the thresholds were too high for the area. In 2016-2017 we reviewed the thresholds and tuned and updated them based on a few recent but most reliable events (Boje, 2017) (Fig. 2b).

At the end of September and beginning of October 2017 two powerful low-pressure systems, located initially north of Newfoundland, brought intense rainfalls over 3-4 days starting on 29 September 2017. The first low-pressure system was supposed to hit the western sector of the region, while the second, which also carried the remnants of the tropical cyclones Maria and Lee (http://www.noaa.gov), was supposed to hit the eastern part of the region, including also the Telemark county and some of the counties in southeastern sec- tor of Norway. MET released a meteorological warning for the region based on available forecasts. Flood and landslide warnings were issued by NVE (Table 6).

The flood forecasting issued a warning at yellow level for Saturday 30 September on Thursday 28 September. On Friday 29 September the flood warning was elevated to orange for the 30 September. On Saturday 30 September the flood warning level was set to red, which stayed on red level for most of the Agder counties for 3 days, followed by an orange day (3 October) and one day yellow (4 October) before the river discharge returned to normal (Table 6).

The landslides thresholds for the area showed high awareness level in Agder, for a period of 2-3 days. The rail and road authorities had already been warned on Thursday 28 in an e-mail, before the first warning was issued. The rail and road authorities use this early information as an important input for the consideration of their contingency level and to initiate mitigation measures such as planning the possible closure of railways and the use of extra personnel.

The first issued warning, on Friday 29 September, was a yellow level for the days of Saturday 30 September and Sunday 1 October (Table 6). On Saturday 30 September, the level for landslide hazard was upgraded to orange and kept at orange for the two following days for parts of the Agder counties, while the rest of the area, including also the county of Telemark, had a yellow level (Fig. 8; Table 6). The hazard level for Telemark was reduced to green on Monday 2 October, but Rogaland remained at a yellow level for one day longer than the Agder counties, until 3 October. Based on these warnings the regional offices of NVE started to interact with the respective counties and municipalities to consider implementation of the emergency plans and to discuss the risk of damage.

During these rainfall events, which lasted from 29 September to 3 October, some of the rain gauges in the area (the Agder counties) received nearly $300 \mathrm{~mm}$ in 3-4 days. Many rain gauges measured precipitation that corresponds to rain from a more than 100-year return period (Gislefoss et al., 2017).

The first intense rainfall started around midnight on 29 September along the coastline of Rogaland, moving eastward through Agder counties the following hours. Most of the rainfall fell on 30 September and 1 October until 04:00. After a break during the day of 1 October, the second strong low- 
Table 6. Daily assessments and issued flood and landslide warnings for Southern Norway, between 30 September and 4 October 2017.

\begin{tabular}{|c|c|c|c|c|c|c|c|c|c|c|c|c|}
\hline \multirow{7}{*}{$\begin{array}{l}\text { Landslide: } \\
\text { Day when } \\
\text { the } \\
\text { assessment } \\
\text { was } \\
\text { performed }\end{array}$} & 3 rd & & & & & & & & & \multicolumn{2}{|c|}{$\begin{array}{c}\text { Rogaland and } \\
\text { Hordaland }\end{array}$} & \\
\hline & 2nd & & & & & & \multicolumn{3}{|c|}{ Agder and Rogaland } & \multicolumn{2}{|c|}{$\begin{array}{l}\text { Agder, Telemark and } \\
\text { Rogaland }\end{array}$} & \\
\hline & 1 st & & & \multicolumn{2}{|c|}{$\begin{array}{l}\text { Agder and Telemark and southern } \\
\text { part of Rogaland }\end{array}$} & $\begin{array}{l}\text { Southern } \\
\text { parts of }\end{array}$ & \multicolumn{3}{|c|}{ Agder, Telemark and Rogaland } & \multicolumn{2}{|c|}{$\begin{array}{l}\text { Agder, Telemark and } \\
\text { Rogaland }\end{array}$} & \\
\hline & 30th & $\begin{array}{l}\text { Agder and } \\
\text { Telemark }\end{array}$ & $\begin{array}{l}\text { Southerm } \\
\text { parts of } \\
\text { Agder }\end{array}$ & \multicolumn{3}{|c|}{ Agder and Telemark } & & & & & & \\
\hline & 29th & \multicolumn{2}{|c|}{ Agder and Telemark } & \multicolumn{3}{|c|}{ Agder and Telemark } & & & & & & \\
\hline & 28th & \multicolumn{2}{|c|}{$\begin{array}{l}\text { E-mail to NPRA and Bane } \\
\text { NOR with information on the } \\
\text { coming weather }\end{array}$} & & & & & & & & & \\
\hline & & \multicolumn{2}{|c|}{ 30th } & \multicolumn{3}{|c|}{ 1st } & \multicolumn{3}{|c|}{ 2nd } & \multicolumn{2}{|c|}{ 3rd } & 4th \\
\hline \multicolumn{13}{|c|}{ Day which the warning was valid } \\
\hline \multirow{7}{*}{$\begin{array}{l}\text { Flood: } \\
\text { Day when } \\
\text { the } \\
\text { assessment } \\
\text { was } \\
\text { performed }\end{array}$} & 3rd & & & & & & & & & $\begin{array}{c}\text { Southem } \\
\text { parts of } \\
\text { Rogaland, } \\
\text { north of } \\
\text { Agder }\end{array}$ & $\begin{array}{l}\text { Southem } \\
\text { parts of } \\
\text { Agder }\end{array}$ & $\begin{array}{c}\text { Southem } \\
\text { parts of } \\
\text { Rogaland and } \\
\text { Agder }\end{array}$ \\
\hline & 2nd & & & & & & Telemark & $\begin{array}{l}\text { Southern parts } \\
\text { of Rogaland, } \\
\text { north of } \\
\text { Agder and } \\
\text { Telemark }\end{array}$ & $\begin{array}{l}\text { Southern } \\
\text { parts of } \\
\text { Agder }\end{array}$ & $\begin{array}{c}\text { Southern } \\
\text { parts of } \\
\text { Rogaland, } \\
\text { north of } \\
\text { Agder }\end{array}$ & $\begin{array}{l}\text { Southern } \\
\text { parts of } \\
\text { Agder }\end{array}$ & $\begin{array}{c}\text { Southern } \\
\text { parts of } \\
\text { Rogaland and } \\
\text { Agder }\end{array}$ \\
\hline & 1st & & & Telemark & $\begin{array}{c}\text { Southern } \\
\text { parts of } \\
\text { Rogaland, } \\
\text { north of } \\
\text { Agder and } \\
\text { Telemark }\end{array}$ & $\begin{array}{l}\text { Southern parts } \\
\text { of Agder }\end{array}$ & Telemark & $\begin{array}{l}\text { Southern parts } \\
\text { of Rogaland, } \\
\text { north of } \\
\text { Agder and } \\
\text { Telemark }\end{array}$ & $\begin{array}{l}\text { Southern } \\
\text { parts of } \\
\text { Agder }\end{array}$ & $\begin{array}{l}\text { Southen } \\
\text { Rogaland } \\
\text { Agder and }\end{array}$ & $\begin{array}{l}\text { arts of } \\
\text { horth of } \\
\text { elemark }\end{array}$ & \\
\hline & 30th & $\begin{array}{l}\text { Southern } \\
\text { parts of } \\
\text { Rogaland, } \\
\text { north of } \\
\text { Agder and } \\
\text { Telemark }\end{array}$ & $\begin{array}{l}\text { Southern } \\
\text { parts of } \\
\text { Agder }\end{array}$ & $\begin{array}{l}\text { Southern } \\
\text { parts of } \\
\text { Rogaland, } \\
\text { north of } \\
\text { Agder and } \\
\text { Telemark }\end{array}$ & Southem par & ts of Agder & Southe & $\begin{array}{l}\text { parts of Rogalan } \\
\text { Telemark }\end{array}$ & gder and & & & \\
\hline & 29th & \multicolumn{2}{|c|}{$\begin{array}{l}\text { Southem parts of Rogaland, } \\
\text { Agder and Telemark }\end{array}$} & \multicolumn{3}{|c|}{$\begin{array}{c}\text { Southem parts of Rogaland, Agder and } \\
\text { Telemark }\end{array}$} & & & & & & \\
\hline & 28th & \multicolumn{2}{|c|}{ Agder and Telemark } & & & & & & & & & \\
\hline & & \multicolumn{2}{|c|}{ 30th } & \multicolumn{3}{|c|}{$1 \mathrm{st}$} & \multicolumn{3}{|c|}{ 2nd } & \multicolumn{2}{|c|}{3 rd } & 4th \\
\hline \multicolumn{13}{|c|}{ Day which the warning was valid } \\
\hline
\end{tabular}

pressure system arrived in the evening of 1 October around 22:00, and the most intense rainfall fell until very early in the morning of 2 October (07:00-08:00).

These rainfall events triggered extensive floods and many landslides (Fig. 9) mainly in the counties of Vest-Agder and Aust-Agder, but some landslides occurred also in Rogaland and Telemark. In total, $80 \%$ of the damages were to private buildings and many people had to evacuate. More than 3300 cases of damages were reported, for a total value of NOK 500 million (EUR 50 million) (Holmqvist and Langsholt, 2017).

The observed return period of flood was between 50 and 100 years in many of the large rivers of Agder. However, in some other rivers, the flood had even longer return periods. In the river Mandalelva, for instance, the flood was the highest registered since 1896. For many of the stations in this region, with long time series, this was the largest flood ever recorded (Holmqvist and Langsholt, 2017) (Figs. 9a, 10).
A preliminary registration (the verification is still in progress) shows that around 60 landslides events occurred between 29 September and 2 October in the counties of Rogaland, Agder, and Telemark. They were reported along the main roads, causing blockage, but houses were also directly affected. The landslides registered were mainly shallow soil slides and planar slides but also rotational and planar slides in clay materials, mainly of marine origin (Fig. 9b). NVE's regional engineers were attending several of the landslide sites. Because of the presence of marine clay deposits in this area, one of the main concerns was the fear that some of the small soil slides could develop into quick-clay slides. Most of landslides occurred during the most intense rainfall, during 30 October and during the night between 1 and 2 October.

The newly updated landslide thresholds for southernmost part of Norway, included Agder counties (Fig. 2b), proved very useful in this situation. This made the forecasters more confident that the high awareness level was necessary. How- 


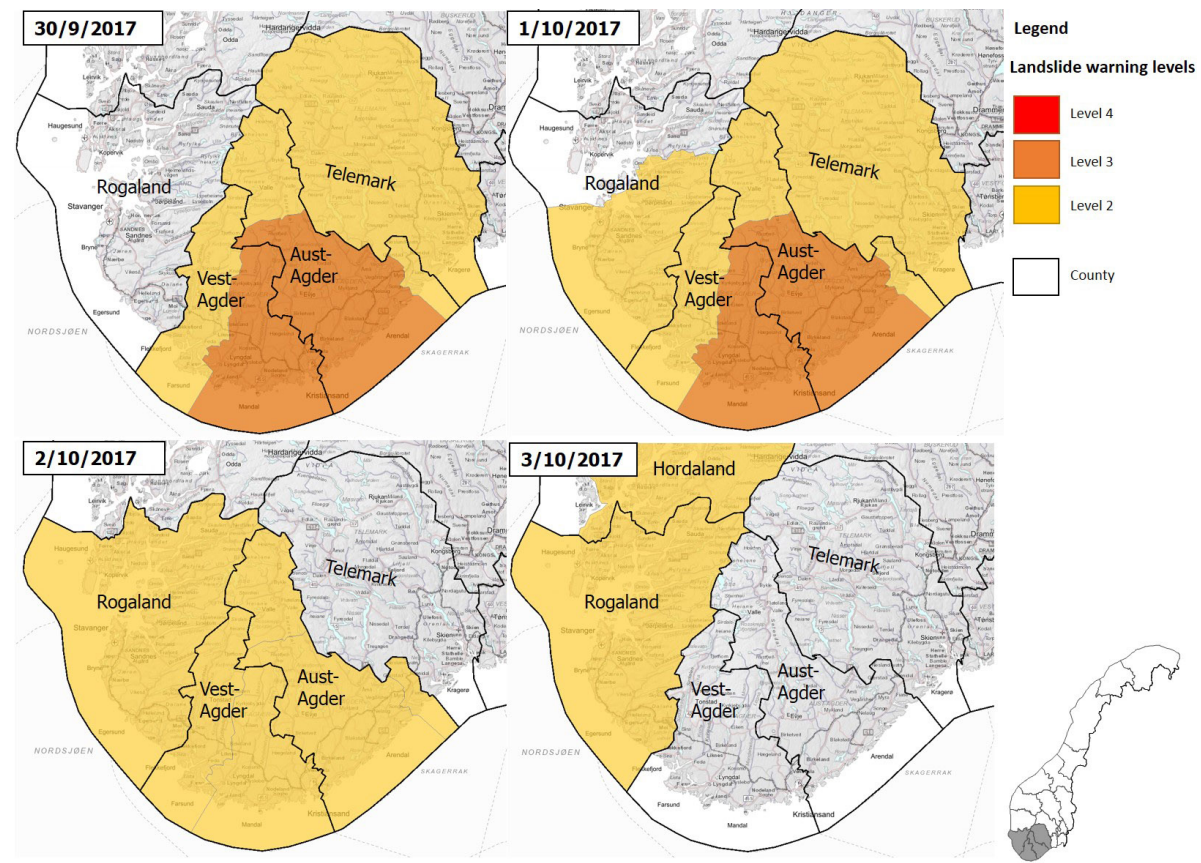

Figure 8. Issued landslide warnings for southern Norway in the period from 30 September to 3 October 2017 (source: xgeo.no).
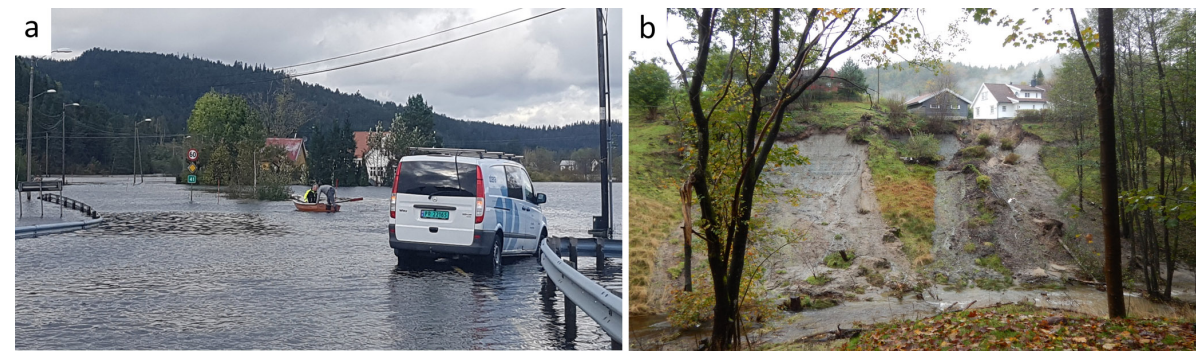

Figure 9. Examples of floods and landslide in Southern Norway, September-October 2017. (a) Flooded county road by the river Tovdalselv, at Drangsholt, Kristiansand, 1 October 2017 (Photo: Turid Haugen, NVE). (b) Shallow debris slide, close to house in Augland Kristiansand, 3 October 2017 (photos: Ellen Davis Haugen, NVE).

ever, since this event was the first in the area after the correction of the thresholds, we did not have experience with the new thresholds, which made the hazard assessment more complicated (Fig. 11). Daily communication between the regional NVE engineers on site and the landslide forecaster on duty helped to understand the ground conditions at local scale.

Due to the issued landslide and flood warnings the public and municipalities became more aware of the severity of the situation, before and during the event. Therefore they were more prepared to face damages and for closing of roads and railways.

\section{Summary}

The development of the rainfall- and snowmelt-induced landslide forecasting and warning service in Norway was possi- ble thanks to a joint initiative across governmental agencies, and due to the fact that we could take advantage of existing IT tools, hydrological models and a hydrogeological network available at NVE as part of the well-established flood forecasting service.

The joint initiative with the MET, NPRA, and Bane NOR was crucial for the establishment of the service and it is still important for the operation of the service (in terms of economy, collection of landslide events, common research and development). The synergy with the flood warning service was significant for a rapid establishment and a rational operation (organization, hydrological monitoring and models, automatic collection of MET observations and forecasts, decision tools, warning routines and communication).

The Norwegian landslide forecasting and warning service uses real-time measurements of hydro-meteorological data (i.e. discharge, groundwater level, soil water content 

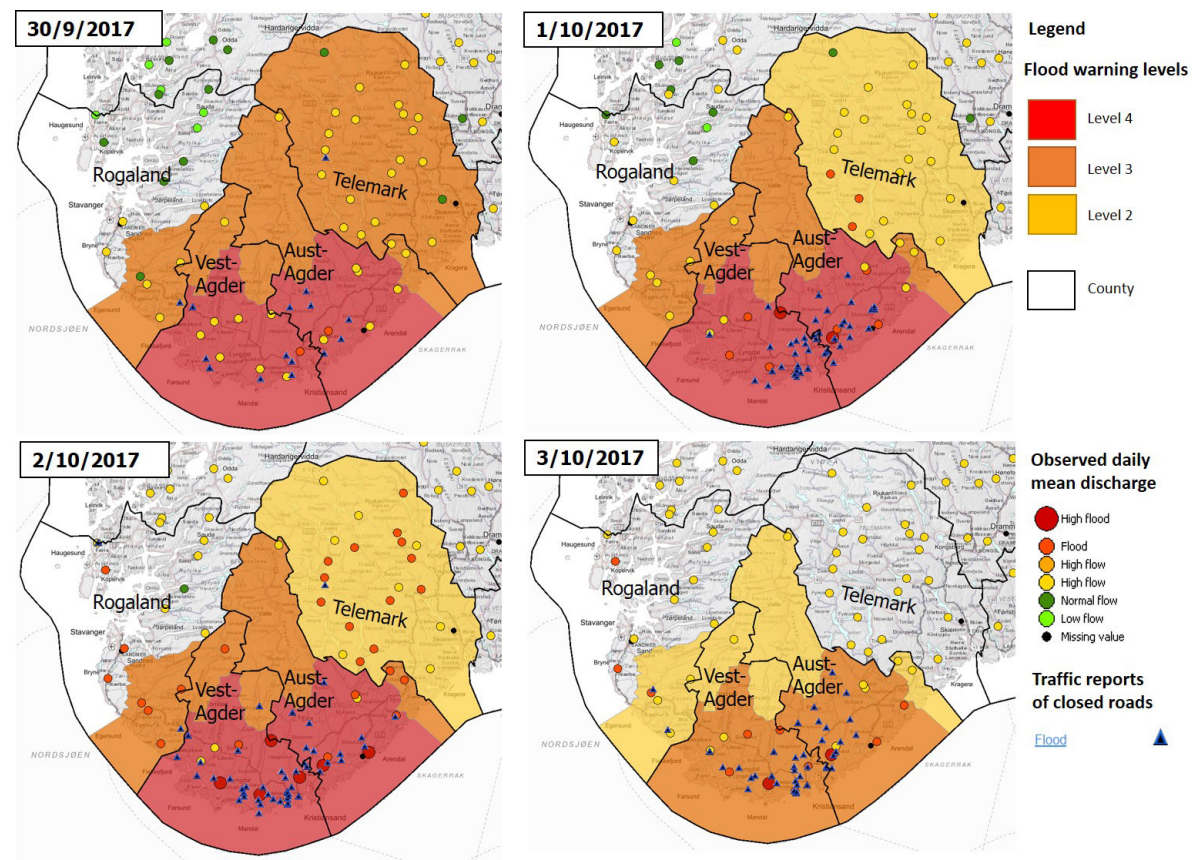

Figure 10. Issued flood warnings for southern Norway in the period from 30 September to 3 October 2017 and water discharge observations. The maps also show locations where roads were closed due to flood and water discharge stations, where the discharge level is classified after flood size at various stations (source: xgeo.no).

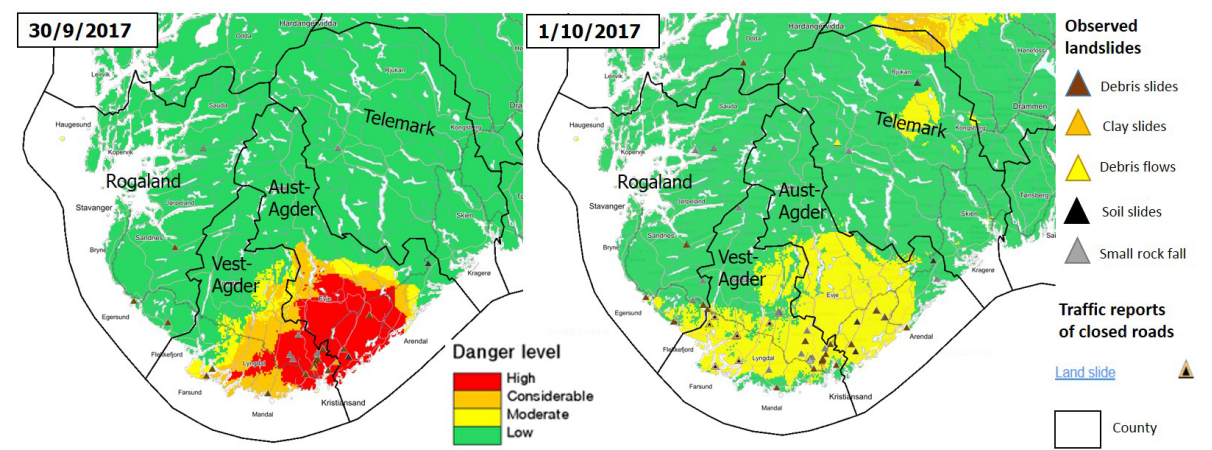

Figure 11. Landslide threshold maps based on observed values (regional landslide hazard threshold for Southern Norway) and distribution of landslide events. Closed roads due to landslides are also viewed in the same map (source: xgeo.no).

and soil temperature, snow water equivalent, meteorological data) and model simulations of the meteorological and hydrological conditions. The thresholds used are based on statistical analyses of historical landslides and simulated hydrometeorological variables (such as rainfall, snowmelt, soil saturation, and depth of frozen ground) and shown as a hydrometeorological index. The service identifies potentially dangerous situations and notifies local emergency authorities and the public up to $66 \mathrm{~h}$ ahead with the purpose that they can take preventive measures. A case study from autumn 2017 has been presented showing how the service is well functioning and useful in order to prevent and reduce damages due to landslides and to save lives.
The first results after 4 years of operations indicate that the flood and landslide services have succeeded as a tool for the road and railway authorities in increasing awareness, preparedness, and risk reduction. NVE's user survey from 2016/2017 (Epinion AS, 2017) confirms that warnings issued by NVE (flood, landslide, snow avalanche) is considered as an "alarm clock" for the municipalities and contingency planners. The service is wanted and appreciated by our most important users, mainly those responsible for emergency response at municipalities and counties, as well as the police.

Our aim and strategy is to provide correct forecasts of both spatial and temporal landslide occurrence and systematically updated landslide bulletins. Therefore, we need 
- reliable weather forecasts;

- reliable real-time data and hydrological models;

- long-term records (data/events) and good hydrological statistics;

- good-quality landslide data;

- roles and responsibilities well defined, and agreed cooperation with key agencies;

- good internal and external coordination;

- precise and understandable communication;

- continuous evaluation, research and development, and improvement;

- skilled and experienced personnel;

Even if the service is quite satisfactory, there are still many challenges and limitations. The hazard assessment, tools for decision making (xGeo, hydrological models, indexes and thresholds) and communication (http://www.varsom.no/) need continuous development and improvement. To improve the accuracy, precision and usefulness of the service, the following areas should be strengthened.

Hazard assessment. The usefulness of the issued warning can be increased considerably by combining landslide hazard and vulnerability data. Therefore hazard and risk maps represent important tools for local authorities that assist them in setting priorities and where to implement the required measures. However, hazard maps and risk maps are not available in the Norwegian municipalities; therefore landslide susceptibility maps available for the entire country could be used by local emergency authorities. These maps have been used to improve the thresholds, but they could support the municipalities by showing where landslides may occur. We need to communicate better the importance of such maps to the users, from a lack of other hazard maps.

Weather forecasts and hydrological models. Reliable warnings require reliable meteorological observations and forecasts. It is still challenging to predict landslides triggered by summer rain showers. The cooperation between MET and NVE has contributed to improved grid data (precipitation and temperature) of observations and forecasts, thus improving estimates of snow, water flow, and other hydrometeorological variables.

The hydrological model used to calculate the water saturation, a parameter used in landslide thresholds, still has a rough resolution in both time $(24 \mathrm{~h})$ and space. The model uses input grid data of precipitation and temperature (observations and forecasts) based on a rough interpolation and does not yet utilize the improved grid data provided by MET at the end of 2016 (Saloranta, 2016; Lussana et al., 2018). An improved version of the model is scheduled to be operative in $2018 / 2019$. It is also appropriate to implement $3 \mathrm{~h}$ resolution.
Therefore, there is still considerable potential for improving the basis used for landslide thresholds.

Better verification of landslide events. The service requires reliable data of landslide events (e.g. correct type, date, place, triggering). This is a prerequisite both for establishment of thresholds and for post-evaluation. For the first evaluation, it is enough to know if landslides have occurred, but to tune the warning levels it is important to know how many landslides occurred under a specific warning level. It is essential to have a good overview of the number and dimension of landslide events that occurred after a rainfall and/or snowmelt episode. NVE maintain a national database; however, the registration is still sparse; i.e. there is no systematic record of events in all regions of Norway. The quality of registrations also varies greatly. There is no consistency in data collection and there are problems with the classification of different landslide types. Release time and location can also be wrong and triggering causes not reported.

A major issue for the verification of the landslide occurrence is that we rely on media and not on systematic field observations. For events on buildings or outside main roads and railways, the data collection is sparse compared to registrations of landslides close to roads and railways.

Upgrading of landslide inventories is mandatory after each forecast in order to have the correct type but also number and dimensions of landslide events.

In Norway most of the data along roads (which is the majority of events) are not recorded by specialists, and hence there is a degree of uncertainty in the quality of the data. The NPRA is now working to ensure that all contractors responsible for driving roads use a standard format and receive periodic training. Because of the poor quality of landslide data and lack of observations, it has been a challenge to tune the landslide thresholds in some regions.

Increase communication and build the user's capacity. The greatest opportunity to increase the benefit of the service is to build expertise among users. Some of the challenges are communicating the warning on time and with sufficient leading time to take actions and the communication of the uncertainty. We have observed that rainfall- and snowmelt-induced landslides are often considered as flood damages (i.e. debris flows and debris slides/avalanches) or snow avalanche damages (i.e. slushflows). There is a need to strengthen the dissemination work specifically aimed at regional and local authorities, as well as the public and the media, so that the warning service itself, the background for alerts and the different landslide types are better understood. The goal is also to get users and recipients of warnings to contribute significantly more, for example registration of hazard signs and landslide events.

Data availability. All the data presented in the document and shown in the figures are publicly accessible. For accessing published landslide and flood warnings http://www.varsom.no/ (NVE, 
2018a), xgeo.no (Barfod et al., 2013) and api.nve.no (NVE, 2018b) may be used. Landslide data, as used in Figs. 2 and 10, can be downloaded from https://gis3.nve.no/map/rest/services/SkredHendelser/ MapServer, or through the application https://temakart.nve.no/link/ ?link=SkredHendelser (NVE, 2018c). Data used for Table 4 can be downloaded from http://api.nve.no/doc/jordskredvarsling/ (NVE, 2018b). Data from Table 5 are available on request to the corresponding author. Data used in Table 6 can be viewed at http: //www.varsom.no/ (NVE, 2018a) or downloaded from http://api. nve.no/doc/jordskredvarsling/ (NVE, 2018b) and http://api.nve.no/ doc/flomvarsling/ (NVE, 2018b). Data shown in Fig. 3 are available in http://www.xgeo.no/ (Barfod et al., 2013). Data shown in Fig. 8 can be viewed at http://www.xgeo.no/ (Barfod et al., 2013) and http://www.varsom.no/ (NVE, 2018a). Data used for Fig. 10 can be viewed at http://www.xgeo.no/ (Barfod et al., 2013), and the landslide data can be downloaded from https://gis3.nve.no/ map/rest/services/SkredHendelser/MapServer, or through the application https://temakart.nve.no/link/?link=SkredHendelser (NVE, 2018c).

Competing interests. The authors declare that they have no conflict of interest.

Special issue statement. This article is part of the special issue "Landslide early warning systems: monitoring systems, rainfall thresholds, warning models, performance evaluation and risk perception". It is not associated with a conference.

Acknowledgements. Special thanks go to our partners: The Norwegian Meteorological Institute (MET), the Norwegian Public Road Administration (NPRA), and the Norwegian Rail Administration (Bane NOR).

Edited by: Samuele Segoni

Reviewed by: Emanuele Intrieri and one anonymous referee

\section{References}

Aaheim, A., Romstad, B., and Sælen, H.: Assessment of risks for adaptation to climate change: the case of land-slides, Mitigation and Adaptation Strategies for Global Change, 15, 763-778, https://doi.org/10.1007/s11027-010-9234-1, 2010.

Aleotti, P.: A warning system for rainfall-induce shallow failures. Engineering Geology, 73, 247-265, https://doi.org/10.1016/j.enggeo.2004.01.007, 2004.

Barfod, E., Müller, K., Saloranta, T., Andersen, J., Orthe, N.K., Wartianen, A., Humstad, T., Myrab $\varnothing$, S., and Engeset, R.: The expert tool XGEO and its application in the Norwegian Avalanche Forecasting Service. Proceeding International Snow Science Workshop Grenoble - Chamonix Mont-Blanc - 2013, available at: http://arc.lib.montana.edu/snow-science/ objects/ISSW13_paper_P1-13.pdf (last access: 20 November 2017), 2013.
Baum, R. L. and Godt, J. W.: Early warning of rainfall-induced shallow landslides and debris flows in the USA, Landslides, 7, 259272, https://doi.org/10.1007/s10346-009-0177-0, 2010.

Bazin, S.: Guidelines for landslide monitoring and early warning systems in Europe, Design and required technology, Project SafeLand "Living With Landslide Risk in Europe: Assessment, Effects of Global Change, and Risk Management Strategies", Deliverable 4.8, 153 pp., available at: https://www.ngi.no/eng/ Projects/SafeLand (last access: 20 November 2017), 2012.

Beldring, S., Engeland, K., Roald, L. A., Sælthun, N. R., and Voks $\varnothing$, A.: Estimation of parameters in a distributed precipitationrunoff model for Norway, Hydrol. Earth Syst. Sci., 7, 304-316, https://doi.org/10.5194/hess-7-304-2003, 2003.

Bell, R., Cepeda, J., and Devoli, G.: Landslide susceptibility modeling at catchment level for improvement of the landslide early warning system in Norway, Proceeding 3rd World Landslide Forum, 2-6 June 2014, Beijing, 2014.

Bergström, S.: The HBV model, in: Computer models of Watershed Hydrology, edited by: Singh, V. P., Water resources publications, Highlands Ranch, 443-476, 1995.

Blikra, L. H. and Kristensen, L.: Monitoring concepts and requirements for large rockslide in Norway, Landslide Science and Practice: Early Warning, Instrumentation and Monitoring, 2, 193200, https://doi.org/10.1007/978-3-642-31445-2_25, 2013.

Boje, S.: Hydrometeorologiske terskel for Jordskredfare på Sørlandet og Østlandet, NVE report 64, available at: http:// publikasjoner.nve.no/rapport/2017/rapport2017_64.pdf (last access: 20 November 2017), 2017 (in Norwegian).

Boje, S., Colleuille, H., Cepeda, J., and Devoli, G.: Landslide thresholds at regional scale for the early warning system in Norway, Proceeding 3rd World Landslide Forum, 2-6 June 2014, Beijing, 2014a.

Boje, S., Colleuille, H., and Devoli, G.: Terskelverdier for utløsning av jordskred i Norge. Oppsummering av hydrometeorlogiske terskelstudier ved NVE i perioden 2009 til 2013, NVE-NIFS report 43, available at: http://publikasjoner.nve.no/rapport/2014/ rapport2014_43.pdf (last access: 20 November 2017), 2014b (in Norwegian).

Bogaard, T. and Greco, R.: Invited perspectives: Hydrological perspectives on precipitation intensity-duration thresholds for landslide initiation: proposing hydro-meteorological thresholds, Nat. Hazards Earth Syst. Sci., 18, 31-39, https://doi.org/10.5194/nhess-18-31-2018, 2018.

Calvello, M.: Early warning strategies to cope with landslide risk, Riv. Ital. di Geot., 2, 63-91, https://doi.org/10.19199/2017.2.0557-1405.063, 2017.

Calvello, M. and Piciullo, L.: Assessing the performance of regional landslide early warning models: the EDuMaP method, Nat. Hazards Earth Syst. Sci., 16, 103-122, https://doi.org/10.5194/nhess16-103-2016, 2016.

Cannon, S. and Ellen, S.: Rainfall conditions for abundant debris avalanches, San Francisco Bay region, California, California Geology, 38, 267-272, 1985.

Capra, L., Coviello, V., Borselli, L., Márquez-Ramírez, V.-H., and Arámbula-Mendoza, R.: Hydrological control of large hurricaneinduced lahars: evidence from rainfall-runoff modeling, seismic and video monitoring, Nat. Hazards Earth Syst. Sci., 18, 781794, https://doi.org/10.5194/nhess-18-781-2018, 2018. 
Cepeda, J.: Calibration of thresholds for Northern Norway, NGI report 20120997-01-TN, 2013a.

Cepeda, J.: Calibration of thresholds for Eastern Norway, NGI report 20120997-02-TN, 2013b.

Cepeda, J., Sandersen, F., Ehlers, L., Bell, R., and De Luca, D.: Probabilistic estimation of thresholds for rapid soil-slides and flows in Norway, NGI report no. 20110253-00-4-R, 2012.

Colleuille, H. and Engen, I. K.: Utredning om overvåking og varsling av løsmasse- og snøskredfare på regionalt nivå, NVE report 16, available at: http://publikasjoner.nve.no/dokument/2009/ dokument2009_16.pdf (last accessed: 20 November 2017), 2009 (in Norwegian).

Colleuille, H., Beldring, S., Mengistu, Z., Wong, W. K., and Haugen, L. E.: Groundwater and Soil water system for Norway based on daily simulations and real-time observations, Proceeding AIH International Symposium, Aquifers Systems Management, Dijon, France 30.05-1.06.2006, published in Aquifer Systems Management Darcy's Legacy in a World of Impending Water, selected Papers on hydrogeology, chap. 43, edited by: Chery, L. and de Marsily, G., 2007.

Colleuille, H., Haugen, L. E., and Beldring, S.: A forecast analysis tool for extreme hydrological conditions in Norway, Poster presented at the Sixth World FRIEND conference, Marocco, 2010, Flow Regime and International Experiment and Network Data, 2010.

Devoli, G. and Dahl, M. P.: Preliminary regionalization and susceptibility analysis for landslide early warning purposes in Norway. NVE-NIFS report nr. 37, available at: http://publikasjoner.nve. no/rapport/2014/rapport2014_37.pdf (last access: 20 November 2017), 2014.

Devoli, G., Kleivane, I., Sund, M., Orthe, N. K., Ekker, R., Johnsen, E., and Colleuille, H.: Landslide early warning system and web tools for real-time scenarios and for distribution of warning messages in Norway, in : Proceeding IAEG 2014, edited by: Lollino, G., Giordan, D., Crosta, G. B., Corominas, J., Azzam, R., Wasowski, J., and Sciarra, N., Engineering Geology for Society and Territory - Volume 2, https://doi.org/10.1007/978-3-319-090573_104, @Springer International Publishing Switzerland, 2014.

Devoli, G., Jorandli, L., Engeland, K., and Tallaksen, L. M.: Largescale synoptic weather types and precipitation responsible for landslides in southern Norway, in: Proceeding 4th WLF 2017, edited by: Mikoš, M., Casagli, N., Yin, Y., and Sassa, K., Advancing Culture of Living with Landslides, Springer, Cham 159167 https://doi.org/10.1007/978-3-319-53485-5_17, 2017.

D'Orsi, R. N.: Landslide risk reduction measures by the Rio de Janeiro city government. Improving the assessment of disaster risks to strengthen financial resilience, Special Joint G20 Publication, Government of Mexico and World Bank, 77-91, 2012.

Dowling, C. A. and Santi, P. M.: Debris flows and their toll on human life: a global analysis of debris-flow fatalities from 1950 to 2011, Nat. Hazards, 71, 203-227, https://doi.org/10.1007/s11069-013-0907-4, 2014.

Ekker, R., Kværne, K., Os, A., Humstad, T., Wartiainen, A., Eide, V., and Hansen, R. K.: regObs - public database for submitting and sharing observations, Proceeding International Snow Science Workshop Grenoble - Chamonix MontBlanc - 2013, 5 pp., available at: http://arc.lib.montana.edu/ snow-science/objects/ISSW13_paper_P5-42.pdf (last access: 20 November 2017), 2013.
Engeset, R.: National Avalanche Warning Service for Norway - established 2013, Proceeding International Snow Science Workshop Grenoble - Chamonix Mont-Blanc - 2013, 10 pp., available at: http://arc.lib.montana.edu/snow-science/ objects/ISSW13_paper_P1-19.pdf (last access: 20 November 2017), 2013.

Engeset, R., Tveito, O. E., Mengistu, Z., Udnæs, H. C., Isaksen, K., and Førland, E. J.: Snow map system for Norway. In: XXIII Nordic hydrological conference, Tallin, NHP Report No48, Tartu, 2004.

Epinion Norge AS: Brukerunders $\varnothing$ kelse for NVEs varslingstjenester, Konsulentrapport, NVE report 47, available at: http:// publikasjoner.nve.no/rapport/2017/rapport2017_47.pdf (last access: 20 November 2017), 2017 (in Norwegian).

Flerchinger, G. N., The Simultaneous Heat and Water (SHAW) Model, Technical Documentation. Norwest Watershed Centre USDA Agricultural Research Service Boise, Idaho, Technical Report NWRC 2000-09, 2000.

Fischer, L., Rubensdotter, L., Sletten, K., Stalsberg, K., Melchiorre, C., Horton, P., and Jaboyedoff, M.: Debris flow modelling for susceptibility mapping at regional to national scale, in: Landslides and Engineered Slopes, edited by: Eberhardt, E., Froese, C., Turner, K., and Leroueil, S., Protecting Society through Improved Understanding, CRC Press, 723-729, 2012.

Fischer, L., Rubensdotter, L., and Stalsberg, K.: Aktsomhetskart jord- og flomskred: Metodeutvikling og landsdekkende modellering, NGU report 2014.019, available at: http://www.ngu. no/upload/Publikasjoner/Rapporter/2014/2014_019.pdf (last access: 20 November 2017), 2014 (in Norwegian).

Gariano, S. L. and Guzzetti, F.: Landslides in a changing climate, Earth-Sci. Rev., 162, 227-252, https://doi.org/10.1016/j.earscirev.2016.08.011, 2016.

Gislefoss, K., Eriksen, B., Wiberg, S., Agersten, S., Førland, E. J., and Thyness, V. W.: MET info Hendelserapport. Nedbørhendelsen i Agderfylkene 30 september-2 oktober 2017, Meteorologi no. 22/2017 (in Norwegian).

Golnaraghi, M.: Early warning systems, UNEP/GRIDArendal Maps and Graphics Library, available at: https://gridarendal-website-live.s3.amazonaws.com/production/ documents/:s_document/252/original/kobetimes.pdf?

1488187778 (last access: 24 May 2018), 2005.

Guzzetti, F., Peruccacci, S., Rossi, M., and Stark, C. P.: The rainfall intensity-duration control of shallow landslides and debris flows: an update, Landslides, 5, 3-17, https://doi.org/10.1007/s10346007-0112-1, 2008.

Hanssen-Bauer, I., Førland, E. J., Haddeland, I., Hisdal, H., Mayer, S., Nesje, A., Nilsen, J. E.Ø., Sandven, S., Sand $\varnothing$, A. B., Sorteberg, A., and Ådlandsvik, B.: Climate in Norway 2100 , a knowledge base for climate adaptation, NCCS report, 1, available at: http://www.miljodirektoratet.no/Documents/ publikasjoner/M741/M741.pdf (last access: 20 November 2017), 2017.

Haque, U., Blum, P., da Silva, P. F., Andersen, P., Pilz, J., Chalov, S. R., Malet, J. P., Auflič, M. J., Andres, N., Poyiadji, E., Lamas, P. C., Zhang, W., Peshevski, I., and Pétursson, H. G.: Fatal landslides in Europe, Landslides, 13, 1545-1554, https://doi.org/10.1007/s10346-016-0689-3, 2017. 
Hestnes, E. A.: Contribution to the prediction of slush avalanches, Ann. Glaciol., 6, 1-4, https://doi.org/10.3189/1985AoG6-1-1-4, 1985.

Hestnes, E. A.: Slushflow hazard - where, why and when? 25 years of experience with slushflow consulting and research, Ann. Glaciol., 26, 370-376, https://doi.org/10.3189/1998AoG26-1370-376, 1998.

Hisdal, H.: Evaluering av snø- og jordskredvarslingen, NVE report 38, available at: http://publikasjoner.nve.no/rapport/2017/ rapport2017_38.pdf (last access: 20 November 2017), 2017 (in Norwegian).

Holmqvist, E. and Langsholt, E.: Flommen på Sørlandet 30.93.10.2017 med oppsummering av flommen 22.-24.10.2017, NVE report 80, available at: http://publikasjoner.nve.no/rapport/ 2017/rapport2017_80.pdf (last access: 20 November 2017), 2017 (in Norwegian).

Hungr, O., Evans, S. G., Bovis, M. J., and Hutchinson, J. N.: A review of the classification of landslides of the flow type, Envir. Eng. Geosci, 7, 1-18, 2001.

Hungr, O., Leroueil, S., and Picarelli, L.: The Varnes classification of landslide types, an update, Landslides, 11, 167-194, https://doi.org/10.1007/s10346-013-0436-y, 2014.

Jansson, P. E. and Karlberg, L.: Coupled heat and mass transfer model for soil-plant atmosphere systems (COUP), Version 5. Royal Institute of Technology, Stockholm, 2014.

Johnsen, E.: Modern forms of communicating Avalanche danger - a Norwegian case. Proceeding at International Snow Science Workshop Grenoble - Chamonix Mont-Blanc - 2013, 5 pp., available at: http://arc.lib.montana.edu/snow-science/ objects/ISSW13_paper_O5-20.pdf (last access: 20 November 2017), 2013.

Kirschbaum, D. B., Stanley, T., and Simmons, J.: A dynamic landslide hazard assessment system for Central America and Hispaniola, Nat. Hazards Earth Syst. Sci., 15, 2257-2272, https://doi.org/10.5194/nhess-15-2257-2015, 2015.

Lussana, C., Saloranta, T., Skaugen, T., Magnusson, J., Tveito, O. E., and Andersen, J.: seNorge2 daily precipitation, an observational gridded dataset over Norway from 1957 to the present day, Earth Syst. Sci. Data, 10, 235-249, https://doi.org/10.5194/essd10-235-2018, 2018.

Meld. St. 22 (2007-2008): Samfunnsikkerhet, samvirke og samordning, available at: https://www.regjeringen.no/ contentassets/ff6481eba7bf495f8532c2eeb603c379/no/pdfs/ stm200720080022000dddpdfs.pdf, last access: 20 November 2017 (in Norwegian).

Meld. St. 15 (2011-2012): Hvordan leve med farene - om flom og skred, available at: https://www.regjeringen.no/ contentassets/65e3e88d0be24461b40364dd61111f21/no/pdfs/ stm201120120015000dddpdfs.pdf, last access: 20 November 2017 (in Norwegian).

MET.: Extreme Weather Events in Europe: preparing for climate change adaptation, MET report ISBN (electronic) 978-827144-101-2, available at: http://www.easac.eu/fileadmin/PDF s/reports_statements/Extreme_Weather/Extreme_Weather_full_ version_EASAC-EWWG_final_low_resolution_Oct_2013f.pdf (last access: 20 November 2017), 2013.

Müller, M.: AROME-MetCoOp: A Nordic Convective-Scale Operational Weather Prediction Model, American Meteorological So- ciety, 32, 609-627, https://doi.org/10.1175/WAF-D-16-0099.1, 2017.

Nadim, F., Pedersen, S. A. S., Schmidt-Thomé, P., Sigmundsson, F., and Engdahl, M.: Natural hazards in Nordic Countries, Episodes, Special Issue for the 33rd Intern. Geol. Congress, Oslo, Norway, 176-184, 2008.

NIFS: NIFS final report 2012-2016, The Natural Hazards program, NIFS report 92, available at: http://www.naturfare. no/_attachment/1659339/binary/1154523 (last access: 22 May 2018), 2016.

NVE: Plan for skredfarekartlegging. Status og prioriteringer innen oversiktskartlegging og detaljert skredfarekartlegging i NVEs regi. NVE report, 14, available at: http://publikasjoner.nve. no/rapport/2011/rapport2011_14.pdf (last access: 20 November 2017), 2011 (in Norwegian).

NVE: Norwegian avalanche, flood and landslide hazard warnings, available at: http://www.varsom.no/, last access: 24 May 2018a.

NVE: Warnings on flood, landslide and avalanche hazard, available at: http://api.nve.no/, last access: 24 May 2018b.

NVE: Landslide data, available at: https:/gis3.nve.no/map/rest/ services/SkredHendelser/MapServer or https://temakart.nve.no/ link/?link=SkredHendelser, last access: 24 May 2018c.

Piciullo, L., Dahl, M.-P., Devoli, G., Colleuille, H., and Calvello, M.: Adapting the EDuMaP method to test the performance of the Norwegian early warning system for weather-induced landslides, Nat. Hazards Earth Syst. Sci., 17, 817-831, https://doi.org/10.5194/nhess-17-817-2017, 2017.

Piciullo, L., Calvello, M., and Cepeda, J. M.: Territorial early warning systems for rainfall-induced landslides, Earth-Sci. Rev., 179, 228-247, https://doi.org/10.1016/j.earscirev.2018.02.013, 2018.

Roald, L.: Flom i Norge, Eds Tom \& Tom, 2013 (in Norwegian).

Saloranta, T. M.: Operational snow mapping with simplified data assimilation using the seNorge snow model, J. Hydrol., 538, 314325, 2016.

Segoni, S., Piciullo, L., and Gariano, S. L., A review of the recent literature on rainfall thresholds for landslide occurrence, Landslide, https://doi.org/10.1007/s10346-018-0966-4, online first, 2018a.

Segoni, S., Rosi, A., Lagomarsino, D., Fanti, R., and Casagli, N.: Brief communication: Using averaged soil moisture estimates to improve the performances of a regional-scale landslide early warning system, Nat. Hazards Earth Syst. Sci., 18, 807-812, https://doi.org/10.5194/nhess-18-807-2018, 2018b.

Solli, A. and Nordgulen, $\varnothing .:$ Bedrock map of Norway and the Caledonides in Sweden and Finland. Scale 1:2000 000, Geological Survey of Norway, Trondheim, 2006.

Stähli, M., Sättele, M., Huggel, C., McArdell, B. W., Lehmann, P., Van Herwijnen, A., Berne, A., Schleiss, M., Ferrari, A., Kos, A., Or, D., and Springman, S. M.: Monitoring and prediction in early warning systems for rapid mass movements, Nat. Hazards Earth Syst. Sci., 15, 905-917, https://doi.org/10.5194/nhess-15905-2015, 2015.

UN/ISDR: Developing Early Warning Systems: a checklist, EWC III 3rd international Conference on Early warning, From Concept to action, UN/ISDR, available at: http://www.unisdr.org/2006/ ppew/info-resources/ewc3/checklist/English.pdf (last access: 20 November 2017), 2006. 
UN/ISDR: ISDR: Terminology, available at: http://www.unisdr.org/ we/inform/terminology (last access: 20 November 2017), 2009.
Washburn, A. L. and Goldthwait, R. P.: Slushflows, Geol. Soc Am. Bull., 69, 1657-1658, 1958. 